NBER WORKING PAPER SERIES

LABOR OUTFLOWS AND LABOR INFLOWS IN PUERTO RICO

\author{
George J. Borjas \\ Working Paper 13669 \\ http://www.nber.org/papers/w13669 \\ NATIONAL BUREAU OF ECONOMIC RESEARCH \\ 1050 Massachusetts Avenue \\ Cambridge, MA 02138 \\ December 2007
}

I am grateful to Gary Becker, Mark Bils, Isaac Ehrlich, Gordon Hanson, Petra Todd, and two referees for helpful comments on a previous draft of this paper, to Trent Alexander of the Minnesota Population Center for generously supplying the Puerto Rican census microdata files, and to Jason Richwine for research assistance. The views expressed herein are those of the author(s) and do not necessarily reflect the views of the National Bureau of Economic Research.

(C) 2007 by George J. Borjas. All rights reserved. Short sections of text, not to exceed two paragraphs, may be quoted without explicit permission provided that full credit, including $@$ notice, is given to the source. 
Labor Outflows and Labor Inflows in Puerto Rico

George J. Borjas

NBER Working Paper No. 13669

December 2007

JEL No. J60,J61

\section{ABSTRACT}

Although a sizable fraction of the Puerto Rican-born population moved to the United States, the island also received large inflows of persons born outside Puerto Rico. Hence Puerto Rico provides a unique setting for examining how labor inflows and outflows coexist, and measuring the mirror-image wage impact of these flows. The study yields two findings. First, the skills of the out-migrants differ from those of the in-migrants. Puerto Rico attracts high-skill in-migrants and exports low-skill workers. Second, the two flows have opposing effects on wages: in-migrants lower the wage of competing workers and out-migrants increase the wage.

George J. Borjas

Kennedy School of Government

Harvard University

79 JFK Street

Cambridge, MA 02138

and NBER

gborjas@harvard.edu 


\title{
LABOR OUTFLOWS AND LABOR INFLOWS IN PUERTO RICO
}

\author{
George J. Borjas*
}

\begin{abstract}
BERNARDO: I think I'll go back to San Juan
ANITA: I know a boat you can get on

BERNARDO: Everyone there will give big cheer

ANITA: Everyone there will have moved here
\end{abstract}

-Stephen Sondheim, West Side Story

\section{Introduction}

In the landmark article that placed migration decisions firmly within the context of the nascent human capital framework, Larry Sjaastad (1962, pp. 81-82) wrote: ${ }^{1}$

Migration poses two broad and distinct questions for the economist. The first, and the one which has received the major attention, concerns the direction and magnitude of the response of migrants to labor earnings differentials over space.

The second question pertains to the connection between migration and those earnings, that is, how effective is migration in equalizing inter-regional earnings of comparable labor? The latter question has received much less attention than the latter. It is also the more difficult of the two.

\footnotetext{
* Robert W. Scrivner Professor of Economics and Social Policy at the John F. Kennedy School of Government, Harvard University; and Research Associate at the National Bureau of Economic Research. I am grateful to Gary Becker, Mark Bils, Isaac Ehrlich, Gordon Hanson, Petra Todd, and two referees for helpful comments on a previous draft of this paper, to Trent Alexander of the Minnesota Population Center for generously supplying the Puerto Rican census microdata files, and to Jason Richwine for research assistance.

${ }^{1}$ The hypothesis that migration is determined by regional wage differences dates back at least to Hicks. In The Theory of Wages (1932, p. 76), Hicks argued that "differences in net economic advantages, chiefly differences in wages, are the main causes of migration."
} 
These two questions have, in fact, dominated the study of regional labor flows over the past half-century. Much of the internal migration literature in the United States documents how regional wage differentials determine the size and direction of the migrant stream (Greenwood, 1997). In contrast, an important part of the international migration literature focuses on the latter question: measuring the impact of immigrants on the receiving country's wage structure (Friedberg and Hunt, 1995). The textbook model of a competitive labor market has clear and unambiguous implications about how wages and employment opportunities in a particular region should adjust to migration-induced labor supply shifts, at least in the short run. In particular, labor inflows should lower the wage of competing workers, while labor outflows should increase the wage. The prediction that inter-regional labor flows help to equalize wages between sending and receiving areas gives migration a central role in any discussion of labor market equilibrium and efficiency (Blanchard and Katz, 1992).

Despite the common-sense intuition behind these implications of the laws of supply and demand, the international migration literature has found it difficult to document the predicted inverse relation between immigration-induced supply increases and wages in receiving countries. It turns out that the nature of the empirical exercise used to measure the wage impact determines the outcome: Studies that relate wage differences across cities to immigration-induced labor supply shocks tend to find little impact (Card, 1991, 2005), while studies that examine the link between immigration and the evolution of the national wage structure find larger effects (Borjas, 2003). 
This paper examines the determinants and consequences of migration flows in Puerto Rico. $^{2}$ These migration flows are of interest for at least two reasons. First, Puerto Rico, with a land area of $8,959 \mathrm{~km}^{2}$ and 3.9 million inhabitants, is smaller than Los Angeles County (which has a land mass of $10,518 \mathrm{~km}^{2}$ and a population of 9.8 million). In Puerto Rico, the local labor market is the national labor market. As a result, one can avoid the technical uncertainty that plagues the existing literature about how to best measure the labor market impact of immigration.

Secondly, even though a sizable fraction of the Puerto Rican-born population moved to the United States in the past few decades, the island was concurrently the recipient of large inflows of persons born outside Puerto Rico. ${ }^{3}$ The Puerto Rican context, therefore, provides a unique setting that should allow us to: (a) examine the economic factors that permit sizable labor inflows and labor outflows to coexist; and (b) observe the predicted mirror-image impact of these labor flows on the Puerto Rican wage structure.

The simultaneous presence of the two opposing flows creates obvious problems for the income-maximizing model of migration, since labor should presumably flow only in the direction of the highest-paying area. It is easy to reconcile two-way flows, however, if different regions offer differential rewards for different types of human capital, and if the opposing labor flows are composed of different types of people. ${ }^{4}$ The Puerto Rican experience, in principle, allows an empirical test of these theoretical implications.

\footnotetext{
2 Recent studies of the Puerto Rican labor market include Davis and Rivera-Batiz (2005) and Enchautegui and Freeman (2005).

${ }^{3}$ More precisely, this labor inflow is not composed of Puerto Ricans who had left the island and subsequently decided to return.

4 A two-way flow of migrants and return migrants could be rationalized within the income-maximizing framework if the initial migration was the result of misinformation about the economic opportunities available in the
} 
Similarly, the concurrent movement of large numbers of workers into and out of Puerto Rico makes the island an inimitable setting for observing how labor flows alter labor market conditions. In most geographic settings that have been analyzed, the countries are either the source of immigrants (as in Mexico), or the recipients of immigrants (as in Canada and the United States). Since labor inflows should reduce the relative wage of competing workers and labor outflows should increase those relative wages, the Puerto Rican experience offers a rare opportunity to determine if relative wages in a particular labor market exhibit this mirror-image response to the two types of labor flows.

The study uses data drawn from the microdata samples of the 1970-2000 Puerto Rican and U.S. Censuses. The empirical analysis yields two important findings - addressing the two distinct questions Sjaastad posed nearly half a century ago. First, the income-maximization hypothesis can help us understand the coexistence of large labor inflows and labor outflows. The human capital of persons who move from Puerto Rico to the United States differs strikingly from the human capital of persons who migrate into Puerto Rico. Because the Puerto Rican wage structure offers relatively high rewards to skills, the island attracts relatively high-skill inmigrants and exports relatively low-skill workers. Secondly, the opposing labor flows do have opposing effects on the wage structure. As predicted by the laws of supply and demand, inmigration lowers the wage of competing workers in the Puerto Rican labor market, while outmigration increases the wage. The wage impact of these labor flows is roughly comparable to that estimated in other countries: a 10 percentage point migrant-induced shift in supply leads to an opposite-signed change of 2 to 4 percent in the wage of competing Puerto Rican workers.

destination, or if the initial migration was used as a "stepping-stone" to acquire skills that are valuable in the source labor market. It is also possible that migration flows respond to differences in amenities across areas, and that the 


\section{The Setting and the Data}

It is instructive to begin by briefly summarizing the history of migration flows in and out of Puerto Rico. ${ }^{5}$ The island became a possession of the United States after the Spanish-American war in 1898. The Jones Act of 1917 granted U.S. citizenship to all Puerto Ricans, implying that Puerto Ricans could move freely to the United States without the legal restrictions facing immigrants from foreign countries.

Despite the absence of legal restrictions, there was relatively little out-migration until after World War II. High unemployment in postwar Puerto Rico and the introduction of low-cost air travel (the six-hour flight from San Juan to New York City cost less than \$50) sparked the initial out-migration. In 1940 only 59.0 thousand Puerto Ricans lived in the United States; by 1950 there were 225.9 thousand, and by 1960 there were 626.9 thousand. Most Puerto Rican outmigrants chose to settle in New York City. In 1970, for instance, 68.9 percent of the Puerto Rican-born population in the United States lived in the New York metropolitan area.

Using Census data that will be described in more detail below, Figure 1 illustrates the trend in the out-migrant share between 1940 and 2000. The out-migrant share is defined as the ratio of the number of Puerto Rican persons living in the United States to the potential Puerto Rican population (in other words, the denominator is the sum of the out-migrants and the total population of Puerto Rico). In 1940, the out-migrant share was 3.1 percent. By 1950, the outmigrant share stood at almost 10 percent, and then rose even more rapidly to 21.1 percent by 1960. In view of the very short time frame in which this remarkable exodus occurred, it is not surprising that Stephen Sondheim had one of the key characters in the 1961 movie version of

optimal sorting of persons across areas reflects heterogeneity in preferences.

${ }^{5}$ See Fitzpatrick (1980) for a more detailed history of Puerto Rican migration to the United States. 
West Side Story predict that the island would soon empty out. Anita was wrong, however. The outflow of Puerto Ricans to the United States slowed down greatly in the 1960s. As a result, the out-migrant share rose only slightly until about 1990, when the outflow seemingly began to accelerate again.

Return migration is relatively common among the Puerto Rican out-migrants (Hernandez, 1967; Ramos, 1992; Enchautegui, 1993; Muschkin, 1993). In 1990, 11.9 percent of the Puerto Rican-born adults enumerated by the Puerto Rican census reported they had resided in the United States at some point during the past decade. ${ }^{6}$ The out-migrant share illustrated in Figure 1 is the net outcome of the two-way flows between Puerto Rico and the United States for the Puerto Rican-born population.

In addition to the outflow and return migration of native-born Puerto Ricans, there is an additional labor flow that has received much less attention and that could have a substantial economic impact. In particular, concurrently with the sizable (net) out-migration of Puerto Rican-born persons, there has also been a sizable in-migration of persons not born in Puerto Rico. In other words, Puerto Rico is an important recipient of immigrants.

Since 1970, the Puerto Rican census microdata reports if a person residing in the island was born outside Puerto Rico. Figure 1 also illustrates the out-migrant and in-migrant shares defined in terms of the native-born Puerto Rican population. ${ }^{7}$ It is evident that this measure of

\footnotetext{
${ }^{6}$ Unfortunately, it is not possible to construct a consistent time series of the rate of return migration. The 1970 Puerto Rican census reports whether a person lived in the United States for at least six months during the past five years; the 1990 census reports whether a person lived in the United States at some point between 1980 and 1990; and the 1980 and 2000 censuses report where a person lived five years prior to the census. In 1970, 13.5 percent of adult (aged 18-64) native-born Puerto Ricans are return migrants; in 1980, 4.0 percent are return migrants; and in 2000, 2.7 percent.

${ }^{7}$ More precisely, the out-migrant share is now defined as the ratio of the number of out-migrants to the sum of the number of out-migrants and the native-born Puerto Rican population, while the in-migrant share is defined as the ratio of in-migrants to the sum of the number of in-migrants and the native-born Puerto Rican population.
} 
the out-migrant share is a little larger than the population-based share; by 2000 , nearly 30 percent of the population of persons born in Puerto Rico resided in the United States. At the same time, the in-migrant share hovers around 10 percent, so that Puerto Rico had an immigrant influx that was proportionately similar to that entering the United States.

Table 1 shows that three national origin groups dominate the in-migrant population in Puerto Rico: persons born in the United States, persons born in Cuba, and persons born in the Dominican Republic. In 1970, almost 10 percent of the immigrants were born in Cuba, and less than 5 percent were born in the Dominican Republic. The pre-1970 Cuban influx can be directly linked to the communist takeover of Cuba, which led to a sizable refugee flow into both the United States and Puerto Rico. Over time, the demographic importance of Cuban immigrants in Puerto Rico diminished. By 2000, only 5.5 percent of the in-migrants were born in Cuba, but 17.1 percent were born in the Dominican Republic. The bulk of the remaining immigrants were born in the United States. Together, these three countries account for 90 percent or more of the foreign-born population in Puerto Rico.

The ancestry of the population of U.S. born persons migrating to Puerto Rico is composed mainly of Americans who have some type of Puerto Rican ancestry (although the information indicating Puerto Rican ancestry is not defined consistently across Censuses). In 1970, about half of the U.S.-born immigrants in Puerto Rico had Puerto Rican ancestry. By the 1990s, the statistic was between 80 and 90 percent. $^{8}$

Despite the numerical importance of the in-migrant influx into Puerto Rico, it is worth emphasizing that out-migration was far larger. In 2000, the in-migrant share stood at 9.4 percent,

\footnotetext{
8 The Hispanic origin variable in the U.S. Census provides information on whether a person has Hispanic ancestry as well as their national origin background. The Hispanic origin information is roughly comparable in the 1980, 1990, and 2000 censuses. The anomalous lower rate of Puerto Rican ancestry for the 1970 sample of U.S.born in-migrants is probably due to the different definition of Hispanic origin in that Census.
} 
while 29.4 percent of the Puerto Rican-born population lived in the United States. As a result, there has been a substantial net population outflow from the island. The net migrant share (i.e., the difference between in-migration and out-migration) has been on the order of a negative 15 to 20 percent over much of the last few decades. In other words, the various labor flows have reduced the size of the Puerto Rican population by around 20 percent.

Not surprisingly, this sizable net labor outflow has been accompanied by convergence in per-capita incomes between the Puerto Rico and the United States. Figure 2 shows the trend in the ratio of (international prices adjusted) per-capita GDP in the two countries. Relative Puerto Rican per-capita GDP almost doubled, from 21 percent to 37 percent, between 1950 and 1965, during the time that the out-migration flow to the United States was at its peak. Since the 1960s, relative incomes in Puerto Rico have continued to rise. By 2003, relatively per capita GDP in Puerto Rico stood at 66 percent.

This paper uses data drawn from microdata Census files available for both Puerto Rico and the United States. I use all of the available data files from the 1970-2000 Puerto Rican Censuses. The 1970 file represents a 3 percent sample of the Puerto Rican population, while all the other files represent a 5 percent sample. The parallel analysis of the U.S. data uses the 19702000 Integrated Public Use Microdata Sample (IPUMS) of the decennial Census. As in Puerto Rico, the 1970 file represents a 3 percent sample, and the 1980 through 2000 files represent a 5 percent sample. The empirical analysis is restricted to men who participate in the labor force. The Data Appendix describes the construction of the various sample extracts and variables in detail.

When analyzing the Puerto Rican census data, I classify workers into two main categories: those born in Puerto Rico and those born outside Puerto Rico. The persons born 
outside Puerto Rico are the "in-migrants." The persons born in Puerto Rico and enumerated by the Puerto Rican census are the "stayers"- the group of Puerto Ricans who chose not to move to the United States.

The Puerto Rican census does not enumerate the Puerto Rican-born persons who moved to the United States and chose to stay there. These out-migrants, however, are enumerated by the U.S. census. Hence a joint analysis of the Puerto Rican and U.S. census data provides information about the size and composition of the (net) out-migrant population. Using the placeof-birth information in the U.S. census, I define anyone born in Puerto Rico and enumerated by the U.S. census as a Puerto Rican out-migrant. It is worth emphasizing that the out-migrants captured by the U.S. census tend to be persons for whom the move was relatively permanent. Out-migrants who have already returned to Puerto Rico are not part of this population and are included in the sample of Puerto Rican stayers.

Since the economic impact of labor flows will depend on the skill composition of the various populations, I classify workers in each of these three groups (i.e., the stayers, the outmigrants, and the in-migrants) into various skill categories. As in Borjas (2003), skill groups are defined in terms of both educational attainment and years of labor market experience.

The distribution of educational attainment in Puerto Rico differs significantly from that of the United States in two important ways. First, high school dropouts make up a much larger fraction of the Puerto Rican workforce. In 1970, the proportion of high school dropouts among working men was 62.7 for Puerto Rico-born persons enumerated in the Puerto Rican Census and 37.6 percent for U.S.-born persons enumerated in the U.S. Census. Even by 2000, the respective statistics were 19.3 and 8.2 percent. 
Second, the typical high school dropout in Puerto Rico has much less schooling than the typical high school dropout in the United States. Consider, for instance, the number of high school dropouts who have 8 or fewer years of schooling. In 1970, 71.9 percent of the high-school dropouts enumerated in the Puerto Rican census had this very low level of schooling. Even by 2000, 50.7 percent of high school dropouts had fewer than 8 years of schooling. It is rarer to find persons with fewer than 8 years of schooling in the population of (U.S.-born) high school dropouts in the United States: the respective statistics are 46.3 percent for 1970 and 20.8 percent for 2000 .

To account for the notable skewing at the bottom end of the Puerto Rican education distribution, I use five categories to define the education groups: (1) high school dropouts with 8 or fewer years of schooling; (2) high school dropouts with 9 to 11 years of schooling; (3) high school graduates (workers who have exactly 12 years of schooling); (4) workers who have some college (13 to 15 years of schooling); and (5) college graduates (workers who have at least 16 years of schooling).

I also classify workers into a particular years-of-experience cohort by using potential years of experience, roughly defined by Age - Years of Education - 6. I assume that age of entry into the labor market is 14 for high school dropouts with less than 8 years of schooling, 16 for high school dropouts with 9-11 years of schooling, 18 for high school graduates, 21 for persons with some college, 23 for college graduates, and then calculate years of experience accordingly. ${ }^{9}$ The analysis is restricted to men who have between 1 and 40 years of experience. Workers are aggregated into ten-year experience groupings (i.e., 1 to 10 years of experience, 11 to 20 years,

\footnotetext{
${ }^{9}$ Because of the assumed age-of-entry for the various education groups, I restrict the analysis to workers aged 14-64. I experimented with alternative assumptions (e.g., all high school dropouts enter the labor market at age 16) and the results are similar to those reported below.
} 
and so on) to capture the notion that workers who have roughly similar years of experience are more likely to affect each other's labor market opportunities than workers who differ significantly in their work experience. It may be preferable to define narrower experience bands (e.g., five-year intervals), but even the 5 percent Puerto Rican censuses have relatively few observations. ${ }^{10}$ The creation of very narrow skill categories would generate much greater measurement error when calculating mean outcomes within cells.

The cells corresponding to educational attainment $(i)$, years of work experience $(j)$, and calendar year $(t)$ define a skill group at a point in time. Let $N_{i j}(t)$ give the number of Puerto Rican stayers (i.e., the number of Puerto Rican-born persons enumerated by the Puerto Rican census) in the $(i, j, t)$ cell; $M_{i j}(t)$ be the corresponding number of in-migrants in Puerto Rico; and $X_{i j}(t)$ be the corresponding number of Puerto Ricans who out-migrated to the United States. Define:

$$
\begin{aligned}
& p_{i j}(t)=\frac{M_{i j}(t)}{M_{i j}(t)+N_{i j}(t)}, \\
& q_{i j}(t)=\frac{X_{i j}(t)}{X_{i j}(t)+N_{i j}(t)} .
\end{aligned}
$$

The variable $p_{i j}(t)$ gives the in-migrant share in the Puerto Rican workforce (i.e., the fraction of the Puerto Rican workforce that was born outside Puerto Rico), while $q_{i j}(t)$ gives the out-migrant share (i.e., the fraction of the Puerto Rican-born workforce that lives in the United States). For

\footnotetext{
10 The total number of working men (with positive earnings) enumerated in each of the Puerto Rican Censuses is as follows: 10,438 in 1970; 16,763 in 1980; 23,029 in 1990; and 24,313 in 2000. The average cell size in each education-experience group is 522 in 1970, 838 in 1980, 1,151 in 1990, and 1,216 in 2000.
} 
expositional convenience, I initially use the convention of defining both the in-migrant and the out-migrant shares as positive numbers.

Figure 3 shows the trends in the estimated in-migration and out-migration shares defined by equations (1) and (2) and estimated in the sample of working men. Note that the in-migrant and out-migrant shares estimated in this sample are far larger than the corresponding population shares illustrated in Figure 1. For example, the out-migrant share in 2000 for the Puerto Rican population was 29.4 percent, as compared to an out-migrant share of 38.6 percent for working men. Similarly, the in-migrant share in the sample of working men (13.6 percent in 2000) is much higher than the corresponding share in the Puerto Rican population (9.4 percent). In fact, the in-migrant share in the Puerto Rican workforce is very similar to the immigrant share in the U.S. workforce. In 2000, 14.7 percent of working men in the United States were foreign-born.

Put differently, the stylized perception of Puerto Rico as a region that has lost a large fraction of its potential workforce to the United States is correct, but incomplete. Immigrants play as large a role in Puerto Rico as they do in the United States.

\section{Labor Flows by Skill}

This section documents how the structure of out-migration and in-migration differs across skill groups. Figure 4 reports the education-specific trends in the out-migrant share of native-born Puerto Rican working men. The out-migrant share is lowest for college graduates, and is highest for workers with 9-11 years of schooling. In 1980, for example, only about 23 percent of the college-educated workforce had left Puerto Rico. In contrast, the out-migrant share 
for high school dropouts with 9-11 years of schooling was over 50 percent during the period (peaking at an astounding 73 percent in 1980). ${ }^{11}$

A straightforward application of the Roy model would suggest that the least educated workers have the most incentive to leave Puerto Rico (Borjas, 1987; Ramos, 1992). After all, regardless of how it is measured, the rate of return to skills is much higher in Puerto Rico than in the United States. Table 2 reports various summary measures of the spread of the wage distribution in Puerto Rico and in the United States, including the variance of log weekly earnings, the residual variance of log weekly earnings, and the experience-adjusted wage gap between college graduates and high school dropouts with 9-11 years of schooling as well as the experience-adjusted wage gap between college graduates and high school graduates. ${ }^{12}$

The summary characteristics reported in Table 2 document two key facts. First, the returns to skills are greater in Puerto Rico than in the United States. ${ }^{13}$ In 1990, for instance, the experience-adjusted wage gap between college graduates and high school graduates was 0.811 in Puerto Rico and 0.623 in the United States. Similarly, the residual variance of log weekly earnings was 0.710 in Puerto Rico and 0.480 in the United States. The Roy model would then predict that a relatively higher fraction of the least-educated Puerto Ricans should be outmigrants.

${ }^{11}$ Note that the out-migrant share for this particular group declined substantially between 1980 and 2000 , suggesting that there was a sizable return migration of these high school dropouts back to Puerto Rico during those two decades.

12 The residual variance of log weekly earnings and the experience-adjusted wage gaps across schooling groups are estimated from a regression of log weekly earnings on fixed effects indicating the five education categories defined in the previous section, and on a quadratic in years of work experience.

13 The estimated variances for the 1990 Puerto Rican wage distribution do not seem consistent with the variances estimated in other censuses. I have been unable to identify the source of this data anomaly. 
Second, the returns to skills have increased at a much faster rate in the United States than in Puerto Rico. For example, the (experience-adjusted) wage gap between college and high school graduates in Puerto Rico rose slightly from 0.81 to 0.85 between 1970 and 2000. In the United States, however, the corresponding log wage gap rose from 0.53 to 0.68 . Similarly, the residual variance in log weekly earnings was 37 percent higher in Puerto Rico than in the United States in 1970 (0.56 as compared to 0.41). By 2000, however, the variances were almost the same: 0.57 in Puerto Rico and 0.53 in the United States. The relatively faster increase in the return to skills in the United States would suggest that the out-migrant share of highly educated workers should have risen the most during the period under study.

The differences in out-migrant shares across education groups illustrated in Figure 4 are partly consistent with these predictions of the Roy model: while the fraction of low-educated Puerto Ricans who moved to the United States was about the same in 1970 as in 2000 (with some noticeable ups-and-downs in between), the out-migrant share for college graduates was rising rapidly. In 1970, the out-migrant share of college graduates was 13.4 percent; by 2000, it had more than doubled to 30.4 percent. These trends are consistent with the fact that the returns to skills were increasing much faster in the United States, encouraging highly educated workers to leave the island.

Note, however, that the data are not entirely consistent with the prediction that, on net, the Puerto Rican out-migrants should be negatively selected. After all, the highest out-migration rate is not observed in the sample of high school dropouts with 0-8 years of schooling, but in the sample of high school dropouts with 9-11 years of schooling. This non-monotonicity in outmigration rates, however, can be explained by a slightly modified version of the traditional Roy model. In particular, suppose that liquidity constraints prevent the least-educated Puerto Rican 
workers from financing the requisite investments required to move to the United States. This would imply that the least skilled among the least-educated workers would find it difficult to move, depressing their out-migration rate. ${ }^{14}$ Once the liquidity constraints are relaxed, those loweducated workers who can afford to leave the island will do so. This pattern seems to be what the data reveal. Out-migrant shares are generally higher for low-educated workers, though they are highest for the "better off" workers within this disadvantaged population.

These Roy model-related insights are corroborated by the selection that characterizes the reverse migration of U.S.-born workers who move to Puerto Rico. As reported in Table 1, roughly 7 to 8 percent of the workforce in Puerto Rico was born in the United States, with close to 80 percent of these U.S.-born immigrants having some type of Puerto Rican ancestry.

By judiciously using the available data, it is possible to roughly estimate the out-migrant share in the population of U.S.-born persons of Puerto Rican ancestry. Since 1970, the U.S. Census reports a measure of Hispanic ancestry for the native-born population. Persons who report being Hispanic are then asked to specify the type of Hispanic background. These data allow the enumeration of the number of U.S.-born persons of Puerto Rican ancestry who reside in the United States. By combining this size-of-population statistic with the number of U.S.-born persons of Puerto Rican ancestry enumerated by the Puerto Rican Census, one can estimate the out-migrant share of this population (i.e., the fraction of the U.S.-born population of Puerto

\footnotetext{
14 The hypothesis of liquidity constraints among the least-educated workers also seems to explain the selection of out-migrants from Mexico (Chiquiar and Hanson, 2005). There is, however, some disagreement on the type of selection that characterizes Mexican emigration; Fernández-Huertas Moraga (2006) and Ibarrarán and Lubotsky (2007) argue that there is unambiguous evidence of negative selection in the subsample of Mexican emigrants.
} 
Rican ancestry that lives in Puerto Rico). In 2000, 10.8 percent of male workers in this group lived in Puerto Rico. ${ }^{15}$

As Figure 5 shows, the skill composition of this population seems to be a mirror image of that of Puerto Ricans choosing to move to the United States. Because Puerto Rico generally offers relatively higher returns to skills than the United States, it is not surprising that the outmigrant shares of U.S.-born Puerto Ricans are highest for college educated workers. In 2000, for example, the out-migrant share of college graduates was 18.9 percent, as compared to 5.5 percent for high school dropouts with 9-11 years of schooling. ${ }^{16}$

The inflow of relatively large numbers of both U.S.-born and foreign-born workers into Puerto Rico substantially altered the skill endowment of the Puerto Rican workforce. Consider, in particular, the supply shifts caused by migration into the Puerto Rican labor market. Figure 6 illustrates the trend in the in-migrant shares for the five education groups. Evidently, inmigration led to a sizable increase in the number of college graduates in the Puerto Rican workforce. In 1970, for example, 26.9 percent of college-educated workers in Puerto Rico were foreign-born, as compared to only about 5 percent of high school dropouts.

In addition to these differences in the in-migrant and out-migrant shares across education groups, there is substantial variation across experience groups (holding education constant). Figures 7 and 8 summarize some of these differences in the estimated supply shifts for outflows and inflows, respectively. The data illustrated in Figure 7, for instance, indicate that for some

\footnotetext{
15 It is important to emphasize that this out-migration rate probably contains a lot of measurement error. First, the definition of Hispanic (and Puerto Rican ancestry) in the 1970 Census is not strictly comparable with the definition in subsequent censuses. Second, the definition of Puerto Rican ancestry differs significantly between the Puerto Rican and U.S. Censuses.

16 It would also be interesting to determine if the skills of immigrants born outside the United States are consistent with the differences in the wage structures between Puerto Rico and the sending countries. It is
} 
education groups out-migrant shares in 1990 tend to be larger for younger workers (e.g., college graduates), while for other groups out-migrant shares tend to be larger for older workers (e.g., high school dropouts with 0-8 years of schooling). Figure 8 shows equally striking variation in the observed in-migrant shares. Among less-educated workers, there is a tendency for inmigration to most increase the supply of younger workers. Among more educated workers, however, in-migrant shares are much more stable across experience groups.

The evidence presented in this section suggests that the type of worker leaving Puerto Rico differs from the type of worker that is moving in. It is easy to provide a striking illustration of just how different the two opposing flows are. In particular, Figure 9 presents a scatter diagram of the in-migrant and out-migrant shares — as defined by equations (1) and (2) calculated for each of the $(i, j, t)$ cells. There is a strong negative correlation between the two variables. The skill groups that experienced the greatest outflows at a particular point in time are also the skill groups that experienced the smallest inflows. The differential skill composition of the opposing flows provides a simple and intuitive explanation for why there can be sizable inflows and outflows in a particular labor market at the same time: The relatively high returns to skills in the Puerto Rican labor market attract high-skill workers and encourage the outflow of low-skill workers.

\section{Determinants of Labor Flows}

Before proceeding to discuss the equilibrating effects of labor flows, it is instructive to investigate if the Puerto Rican experience confirms a key prediction of economic theory - that the workers who incur the cost of moving are the ones who have the most to gain. Although the 
presence of selection biases in calculating potential wages in alternative regions prevents a complete analysis (unless much more statistical structure is imposed on the data), the results clearly suggest that the flows of workers in and out of Puerto Rico move in precisely the right direction.

Let $w_{i j}^{P R}(t)$ denote the mean value of the log weekly wage that Puerto Rican-born men who have education $i$ and experience $j$ would earn if employed in Puerto Rico at time $t$. Let $w_{i j}^{U S}(t)$ be the alternative log wage that this group of workers would earn in the U.S. labor market. For given migration costs, Puerto Rican natives should be more likely to migrate to the United States the greater the wage gain $w_{i j}^{U S}(t)-w_{i j}^{P R}(t)$. Both the U.S. and the Puerto Rican wage structures changed significantly between 1970 and 2000. As a result, there is a great deal of variation in the potential wage gain associated with moving to the United States across skill groups and over time.

Equation (2) defines $q_{i j}(t)$, the out-migrant share from Puerto Rico as of time $t$. Define the decadal change in the out-migrant share and in the wage gain as $\Delta q_{i j}(t)=q_{i j}(t)-q_{i j}(t-1)$ and $\Delta\left[w_{i j}^{U S}(t)-w_{i j}^{P R}(t)\right]=\left[\left(w_{i j}^{U S}(t)-w_{i j}^{P R}(t)\right)-\left(w_{i j}^{U S}(t-1)-w_{i j}^{P R}(t-1)\right)\right]$. Consider the regression model:

$$
\Delta q_{i j}(t)=\beta \Delta\left[w_{i j}^{U S}(t)-w_{i j}^{P R}(t)\right]+\text { other variables }+\varepsilon_{i j}(t)
$$

Equation (3) relates the decadal change in the out-migrant share to the decadal change in the relative Puerto Rican wage. The coefficient $\beta$ should be positive as long as the probability of migrating from Puerto Rico to the United States responds to economic incentives. Note that the 
differencing of the data within education-experience cells implies that $\beta$ is being identified from changes in the relative wage of a particular skill group. The regressions weigh the observations by the sum of sampling weights used to calculate the out-migrant share at time $t$, and the standard errors are clustered by education-experience cells to adjust for possible serial correlation. ${ }^{17}$

One problem with estimating the regression model in (3) is that we do not observe what the typical worker in cell $(i, j, t)$ would earn if he were to migrate to the United States. Instead, we observe the mean wage of the self-selected group of workers who chose to migrate. If the selection of Puerto Ricans into the out-migrant flow were determined solely by observed characteristics (in particular, education and experience), we could define the alternative wage $w_{i j}^{U S}(t)$ as the wage that Puerto Rican out-migrants in that particular cell actually earn in the United States. This wage can be calculated from the respective U.S. Census. Similarly, I define $w_{i j}^{P R}(t)$ as the average log weekly wage that native-born Puerto Ricans in cell $(i, j, t)$ actually earn in Puerto Rico. All earnings are deflated to 1990 constant dollars using either the U.S. or Puerto Rican CPI.

Using these definitions, the top panel of Table 3 reports the estimated coefficients from two alternative specifications of the model in equation (3). In column 1, the regression model does not include any other regressors. There is a positive and significant correlation between the out-migrant share in a skill group and the net wage gain associated with moving to the United States. A 10-percentage point increase in the wage gain increases the out-migrant share by one percentage point. Column 2 adds a vector of period fixed effects to allow for differences in other

\footnotetext{
${ }^{17}$ I normalized the sum of weights to equal 1 in each cross-section to prevent the more recent censuses from contributing more to the estimation simply because Puerto Rico's population increased over time.
} 
factors that are time-specific (such as migration costs). The inclusion of these fixed effects strengthens the basic result: a 10-percentage point increase in the wage gap raises the outmigration rate by 1.5 percentage points.

Columns 3-4 of the top panel of Table 3 report the coefficients from a slightly more general specification of the regression model in equation (3). In particular, suppose that:

$$
\Delta q_{i j}(t)=\beta_{1} \Delta w_{i j}^{U S}(t)+\beta_{2} \Delta w_{i j}^{P R}(t)+\text { other variables }+\varepsilon_{i j}(t),
$$

where $\Delta w_{i j}^{U S}(t)=\left[w_{i j}^{U S}(t)-w_{i j}^{U S}(t-1)\right]$ and $\Delta w_{i j}^{P R}(t)=\left[w_{i j}^{P R}(t)-w_{i j}^{P R}(t-1)\right]$. This specification allows for the separate identification of the push and pull factors in the determination of outmigration. The coefficients reported in the top panel of Table 3 indicate that the out-migrant share is higher the greater the wage in the U.S. labor market, and is lower the greater the wage in the Puerto Rican labor market—although some of the coefficients are not precisely estimated.

An obvious problem with the regression results is that the actual earnings of the Puerto Rican out-migrants in the U.S. labor market may not be the correct measure of the alternative wage facing the typical Puerto Rican worker in Puerto Rico. In principle, one could adjust for this selection problem by adding more structure to the statistical model. Such an analysis would likely be unconvincing since there are relatively few variables in the data that would allow identification of alternative wages on the basis of exogenous variation in opportunities, rather than on the basis of statistical assumptions.

A simpler approach is to evaluate the sensitivity of the results to using alternative definitions of the potential U.S. wage. The middle panel of Table 3 replicates the analysis by defining $w_{i j}^{U S}(t)$ as the average wage earned by the typical native-born worker in the United 
States in cell $(i, j, t)$. The key difference between the two measures of $w_{i j t}^{U S}$ is that the one used in the top panel of the table uses only the sample of Puerto Rican-born workers in the United States, while the one used in the middle panel aggregates over all U.S.-born workers. Despite the substantive difference in the two definitions of the alternative wage, the estimated regression coefficients are roughly similar. A 10 percent increase in the wage gap between the United States and Puerto Rico still leads to a one- to two-percentage point increase in the out-migration rate.

Finally, as noted earlier, most of the Puerto Rican immigrants in the United States settle in the New York metropolitan area. This suggests that another possible definition for $w_{i j}^{U S}(t)$ is the average wage earned by the typical Puerto Rican immigrant in that region. ${ }^{18}$ The bottom panel of Table 3 re-estimates the regression using this measure of the alternative wage. It is evident that the coefficient $\beta$ is still positive. In the specification that contains the period fixed effects, a 10 percent increase in the net wage gain from moving increases the out-migration rate by 3.0 percentage points.

An endogeneity problem may bias the estimate of $\beta$ in equation (3), and of $\beta_{1}$ and $\beta_{2}$ in equation (4). A positive estimate of $\beta$ in equation (3), for example, implies that the net size of migration flows responds positively to the wage differential between receiving and sending regions. It is also the case, however, that the resulting outflow from Puerto Rico to the United States must have affected the wage structure in both areas. In particular, the outflow would presumably lower wages in the U.S. labor market and raise wages in the Puerto Rican labor market. In other words, the endogeneity of the inter-regional wage gap creates a negative

18 Although the 1980-2000 U.S. Censuses report the metropolitan area of residence for all observations, only a third of the sample in the 1970 U.S. Census reports that information. To maintain a relatively large sample size, the 1970 New York wage is defined to be the average wage of native-born workers in New York State. 
correlation between the measured out-migrant share and the net wage gain resulting from migration. As a result, the coefficients reported in Table 3 underestimate the responsiveness of migration flows to regional wage differentials. In the next section, I present one approach for correcting the coefficients for this potential endogeneity.

It is of interest to develop a parallel analysis of the determinants of in-migration flows into Puerto Rico. As noted earlier, there are two main types of in-migrants: workers who were born in the United States and move to Puerto Rico (and at least 80 percent of these workers have Puerto Rican ancestry after 1980), and workers who were born in other countries (particularly Cuba and the Dominican Republic) and migrate to Puerto Rico. Although it is impossible to analyze the determinants of out-migration rates for workers from Cuba or the Dominican Republic, it is possible to estimate an analogous model for the first group of workers - the U.S.born migrants from the United States to Puerto Rico. To determine the determinants of this influx, consider the regression model:

$$
\Delta p_{i j}^{*}(t)=\gamma \Delta\left[w_{i j}^{U S}(t)-w_{i j}^{P R}(t)\right]+\text { other variables }+\varepsilon_{i j}(t)
$$

where $\Delta p_{i j}^{*}(t)$ is the decadal change in the out-migrant share of U.S.-born workers as a fraction of the number of U.S.-born persons who have Puerto Rican ancestry. The income-maximization hypothesis implies that the coefficient $\gamma$ should be negative.

The nature of the available data makes it difficult to find operational definitions for $w_{i j}^{U S}(t)$ and $w_{i j}^{P R}(t)$. I use the Puerto Rican census to calculate the average wage earned by U.S.born immigrants in Puerto Rico, and define $w_{i j}^{P R}(t)$ accordingly. Second, there is no direct 
information about how much the U.S.-born immigrants in Puerto Rico earned in the United

States prior to their migration. I approximate the average wage $w_{i j}^{U S}(t)$ by either the average wage of workers in a particular skill group who have Puerto Rican ancestry, the average wage of native-born workers in the United States, or the average wage of native-born workers in the New York metropolitan area.

Table 4 reports the regression results. The estimated coefficient $\gamma$ is negative and significant in the specifications reported in columns 1 and 2. The results, however, are more mixed in the specification that allows for separate identification of push and pull factors - with the results depending on the definition of the alternative potential U.S. wage. Overall, the evidence suggests that a 10-percentage point increase in the wage gap between the United States and Puerto Rico reduces the probability that a U.S.-born person of Puerto Rican ancestry moves to Puerto Rico by 1 to 2 percentage points. ${ }^{19}$

\section{Consequences of Labor Flows: Migration as an Equilibrating Mechanism}

As noted earlier, because immigrants tend to cluster in a small number of cities in most receiving countries, many studies estimate the labor market impact of immigration by comparing economic conditions across localities in the receiving country. These studies calculate the correlation between measures of immigrant penetration in local labor markets and measures of economic outcomes, such as wages (Altonji and Card, 1991; Card, 2001; and LaLonde and

\footnotetext{
${ }^{19}$ Note that even though high-skill workers do relatively better in Puerto Rico, many of the high-skill migrants from the United States to Puerto Rico may actually be taking a nominal wage cut because of the sizable difference in wage levels between the two regions. This implies, of course, that there are important differences in relative prices (e.g., housing) or amenities that are being ignored in the analysis. It seems plausible to argue that these factors may become more important as workers near retirement age. However, the descriptive data in Figure 5 suggests that there has actually been a reduction in the relative propensity of older U.S.-born workers to migrate to Puerto Rico.
} 
Topel, 1991). The sign of this spatial correlation is interpreted as indicating the direction in which supply shifts affect wages; a negative correlation would suggest that immigration-induced increases in labor supply lower wages. Although there is a lot of dispersion across studies, the estimated spatial correlations cluster around zero. This weak correlation has been interpreted as indicating that immigration has little impact on the receiving country's wage structure.

The potential problems associated with using regional wage differences to measure the labor market impact of immigration are now well understood (Borjas, Freeman, and Katz, 1997). For instance, natives (and pre-existing immigrants) may respond to the adverse wage impact of immigration by moving their labor or capital to other cities. These regional flows diffuse the impact of immigration across all regions, suggesting that the labor market impact of immigration may be measurable only at the national level. ${ }^{20}$ Borjas (2003) used this insight to examine how the aggregate wage trends of U.S. workers were related to the immigrant supply shocks affecting those groups. The national-level evidence indicated that the wage growth experienced by narrowly defined skill groups was strongly and inversely related to immigration-induced supply increases. This approach has now been applied to such diverse contexts as Canada (Aydemir and Borjas, 2007) and Mexico (Mishra, 2007) with similar conclusions: supply shifts induced by international migration lead to an opposite-signed change in the wage of competing workers. ${ }^{21}$

20 There is little consensus on whether the internal migration decisions of native workers are, in fact, influenced by immigration (Card, 2001; Borjas, 2006). The observed spatial correlation is also contaminated by the possibility that immigrants choose to settle in high-wage areas of the host country and by measurement error in the observed immigrant supply shock in the local labor market.

${ }^{21}$ Bonin (2005) reports some contradictory evidence using the national level approach. Bonin finds that supply shocks in Germany lower wages in the German labor market, but by much less than in the Borjas (2003) study. The German census, however, does not provide direct information on immigration status, so that the data cannot distinguish between foreign citizens born abroad and foreign citizens born in Germany. As a result, it is unclear exactly what type of supply shock is being measured. 
In this section, I employ this methodological approach to investigate if the Puerto Rican wage structure responded to the labor inflows and outflows documented in the previous sections. It is worth noting that the application of the Borjas (2003) framework to the Puerto Rican data may be illuminating because, given Puerto Rico's size, the local labor market is the national labor market.

As in my earlier work, I analyze the relation between the evolution of the wage structure and labor flows by using the education-experience skill groups defined above. The construction of the various groups, of course, implicitly assumes that workers with the same level of schooling but with different levels of experience are imperfect substitutes in production (Welch, 1979; Card and Lemieux, 2001). ${ }^{22}$

The analysis focuses on the impact of labor flows on the earnings of Puerto Rican-born workers enumerated by the Puerto Rican census - in other words, I examine the impact of labor flows on the earnings of stayers. In addition to the sample restrictions noted in Section II, the construction of mean earnings for each education-experience-time cell uses only those workers who reported positive earnings in the calendar year prior to the Census. The sample includes both salaried and self-employed workers.

Let $y_{i j}(t)$ denote the mean value of a particular labor market outcome for men who have education $i$, experience $j$, and are observed at time $t$. The empirical analysis differences these data within each decade, so that $\Delta y_{i j}(t)=y_{i j}(t)-y_{i j}(t-1)$, and estimates the regression model:

22 The analysis also ignores the possibility that labor flows in and out of a particular skill group affect the wages of other skill groups. The estimation of these cross-effects would require a much more detailed specification of the production technology (such as the three-level CES framework in Borjas, 2003). Given the relatively small number of observations available in the Puerto Rican data, the specification of a full-blown structural model would probably lead to imprecise (and unconvincing) estimates of the underlying technological parameters. 


$$
\Delta y_{i j}(t)=\theta_{1} \Delta p_{i j}(t)+\theta_{2} \Delta q_{i j}(t)+I+J+T+(I \times T)+(J \times T)+\varphi_{i j}(t),
$$

where $I$ is a vector of fixed effects indicating the group's educational attainment; $J$ is a vector of fixed effects indicating the group's work experience; and $T$ is a vector of fixed effects indicating the time period. The interactions $(I \times T)$ and $(J \times T)$ account for the returns to education and experience changed over time. Finally, the regressions weigh the observations by the sum of sampling weights used to calculate the variable $y_{i j}(t)$ and the standard errors are clustered by education-experience cells.

The dependent variables used to estimate equation (6) are the mean of log annual earnings and log weekly earnings for each skill group, as well as the fraction of weeks worked during the calendar year prior to the Census (defined as weeks worked divided by 52 in the sample of all persons, including non-workers). Model 1 of Table 5 reports the estimates of the coefficients $\theta_{1}$ and $\theta_{2}$ from OLS regressions.

Consider initially the results for the specification that uses the log weekly earnings of the skill group as the dependent variable. The key implication of economic theory - that the in- and out-migration rates should have opposing effects on the earnings of Puerto Rican stayers - is strongly confirmed by the data. A larger out-migration flow increases the wage of those who remain in the island, while a larger in-migration flow decreases their wage.

The coefficient of the out-migrant share is +0.537 , with a standard error of 0.185 . It is easier to interpret this coefficient by converting it to an elasticity that gives the percent change in wages associated with a percent change in labor supply. Throughout the paper, I have used the expositional device of defining both in-migrant and out-migrant shares as positive numbers 
(hence leading to the opposing signs of the two coefficients in Table 5). To avoid confusion in the interpretation of a "wage elasticity," however, it is best to explicitly define out-migration as a negative number. Let $x_{i j}(t)=-X_{i j}(t) / N_{i j}(t)$, or the percentage decrease in the size of group $(i, j, t)$ attributable to out-migration. It is easy to show that the wage elasticity is:

$$
\frac{\partial \log w_{i j}(t)}{\partial x_{i j}(t)}=-\theta_{2}\left[1-q_{i j}(t)\right]^{2}
$$

In 2000, the out-migrant share from Puerto Rico was 38.6 percent. Equation (7) implies that the wage elasticity associated with out-migration (evaluated at the mean value of the out-migrant share) can be obtained by multiplying $-\theta_{2}$ by approximately 0.4 . The wage elasticity for weekly earnings is then -0.21 (or $-0.537 \times 0.4$ ), with a standard error of 0.07 . Put differently, a 10 percent migration-induced reduction in the number of workers in a particular skill group increases the wage of the Puerto Rican workers left behind by 2.1 percent.

The coefficient of the in-migrant share is -0.543 , with a standard error of 0.269 . By using an analogous derivative to that defined in equation (7), one can calculate the wage elasticity associated with in-migration. In 2000, the in-migrant share in Puerto Rico was 13.6 percent. The wage elasticity associated with in-migration can then be obtained by multiplying the estimated $\theta_{1}$ by approximately 0.7 . The wage elasticity of in-migration is then equal to -0.40 (or $-0.573 \times$ 0.7), with a standard error of 0.19. A 10 percent immigration-induced increase in supply, therefore, reduces wages by about 4 percent. Although the estimated wage elasticity of in- 
migration is twice the size as the estimated wage elasticity of out-migration, the hypothesis that the two elasticities are the same cannot be rejected..$^{23}$

The estimated wage elasticity of -0.2 to -0.4 is roughly similar to those estimated in other geographic settings using the same conceptual framework. Borjas (2003) estimated the wage elasticity associated with immigrant flows in the U.S. labor market to be -0.40 ; Aydemir and Borjas (2007) estimated the corresponding elasticity for the Canadian labor market to be -0.32; and Mishra (2007) estimated the wage elasticity associated with out-migration flows in the Mexican labor market to be -0.44 . The Puerto Rican context is unique in that it allows the estimation of equilibrating responses to both inflows and outflows in the same market at the same time - and these wage responses seem to be relatively similar to those found in other labor markets despite the very different institutional, social, and economic settings.

Given the similarity of the effects of in-migration and out-migration coefficients in the log weekly earnings regression, it is not surprising that a regression of the log weekly wage on the net migration rate (defined as the difference between the in-migration and out-migration rates) leads to a similar wage effect. Model 2 of Table 5 reports that the coefficient of the net migration rate in the log weekly earnings regression is $-0.539(0.165)$. The net out-migrant share in 2000 was 25 percent, suggesting that the wage elasticity associated with a 10 percent migrantinduced (net) shift in supply is approximately $-0.30 .{ }^{24}$

23 The difference between the two elasticities is 0.19 , and this difference has a standard error of 0.20 .

${ }^{24}$ Although the first-difference regression model used to estimate the coefficients reported in Table 5 has 60 skill-group-time cells and includes education-time and experience-time interactions, the regression still has 34 degrees of freedom. The evidence suggests that the regression specification in equation (6) does not seem "oversaturated" with fixed effects. However, the estimated wage impact of migration flows is sensitive to the exclusion of some of the interactions, particularly the education-time fixed effects. To illustrate, suppose that the education-time and experience-time interactions are both excluded from the model. The coefficient of the net migrant share then falls to $-0.193(0.124)$. Given the sizable education-related changes in the wage structure during the period, the 
One potential problem with the least squares estimates of the wage elasticities is that the in-migrant and out-migrant shares included as regressors may be endogenous: incomemaximizing behavior on the part of migrants generates a negative correlation between the wage level in the Puerto Rican labor market and the out-migrant share, and a positive correlation between wages in Puerto Rico and the in-migrant share. In other words, the estimated wage elasticities (in absolute value) underestimate the true impact of labor flows on Puerto Rican wages. I will discuss this issue in more detail shortly.

Table 5 also documents that the labor supply of the Puerto Ricans who remained in the island is positively affected by the out-migration of their compatriots and negatively affected by the in-migration of foreign-born persons. For instance, there is a negative correlation between the fraction of weeks worked by the typical Puerto Rican stayer and the in-migrant share, and a positive correlation between the fraction of weeks worked and the out-migrant share. The coefficient of the net migrant share is -0.248 , with a standard error of 0.090 . This coefficient implies that a 10-percentage point migrant-induced net reduction in the supply of workers increases the fraction of weeks worked by 1.4 percentage points.

In sum, a simple application of the laws of supply and demand helps to explain how the Puerto Rican wage structure responds to migration-induced supply shifts. Labor inflows reduce wages and labor supply; labor outflows increase wages and labor supply.

preferred specification should include these interactions. The estimated coefficient is robust once the education-time interactions are included in the regression model. For example, the coefficient of the net migrant share in the regression that only excludes the experience-time interactions is $-0.600(0.112)$. 


\section{Joint Determination of Migration and Wages}

The regressions reported in Tables 3 and 5 define the system that simultaneously determines out-migration out of Puerto Rico as well as the wage in Puerto Rico for workers left behind. For expositional convenience, I summarize the two-equation regression model here:

$$
\begin{aligned}
& \Delta q_{i j}(t)=\beta_{1} \Delta w_{i j}^{U S}(t)+\beta_{2} \Delta w_{i j}^{P R}(t)+\text { other variables }+\varepsilon_{i j}(t), \\
& \Delta w_{i j}^{P R}(t)=\theta_{1} \Delta p_{i j}(t)+\theta_{2} \Delta q_{i j}(t)+\text { other variables }+\varphi_{i j}(t) .
\end{aligned}
$$

As noted above, income maximization on the part of migrants suggests that the estimated parameters understate the response of migration flows to wage changes, as well as understate the impact of labor flows on the wage.

The model's specification suggests a simple (though imperfect) solution to the endogeneity problem faced in estimating the vector $(\beta, \theta)$. In particular, let the decadal change in the potential wage in the United States be an exogenous shifter in the out-migrant share equation, and let the decadal change in the in-migrant share into Puerto Rico be an exogenous shifter in the

Puerto Rican wage equation. Because the assumption that $\Delta w_{i j}^{U S}(t)$ and $\Delta p_{i j}(t)$ are valid instruments may not be strictly correct, I will discuss below how any resulting biases might change the nature of the conclusions.

Table 6 reports the IV coefficients estimated from two alternative specifications of the two-equation system..$^{25}$ Columns $1 \mathrm{a}$ and $1 \mathrm{~b}$ estimate the model as summarized in equations (4) and (6), while columns $2 \mathrm{a}$ and $2 \mathrm{~b}$ estimate the model in terms of the impact of net differences 
(i.e., by using the net wage gain and the net migrant share). The "other variables" in the regression models include the vector of education-time and experience-time interactions in equation (6).

By comparing the results reported in Table 6 with the corresponding results reported in Tables 3 and 5, it is evident that the endogeneity-corrected effects are often numerically larger than those obtained from the earlier specifications. Consider the impact of the U.S. and Puerto Rican wage on the out-migrant share $q_{i j}(t)$. The coefficients reported in Table 6 imply that a 10 percent increase in the potential U.S. wage raises the net migrant share by 2.9 percentage points. The labor flows in and out of Puerto Rico also tend to have larger effects on Puerto Rican wages. A 10 percent increase in the net migrant share reduces the average Puerto Rican wage by 4.3 percent.

These results should be interpreted with caution as there are reasons to suspect that the instruments are not strictly valid. The key instrument in equation (6) is the mean alternative wage in the U.S. labor market (which affects the out-migration rate, but is assumed not to directly influence Puerto Rican wages). If Puerto Rican and U.S. wages move in tandem (perhaps because of the interconnectedness between the two economies), the IV coefficient of $\theta_{1}$ would likely be positively biased. Given the disparity in economic outcomes between the two regions over many decades, however, it may well be that this correlation is not very strong.

Similarly, the key instrument used to estimate equation (4) is the in-migrant share in the Puerto Rican workforce (which affects Puerto Rican wages, but does not directly influence the out-migration decision of Puerto Ricans). In this case, the IV estimate may be underestimating the true impact of a change in the Puerto Rican wage on out-migration rates. There is a very

\footnotetext{
${ }^{25}$ All of the regression models estimated in Table 6 define the potential U.S. wage as the average wage
} 
strong negative correlation between in-migrant and out-migrant shares in the data. If the unobserved factors that lead to more Puerto Ricans leaving Puerto Rico also discourage foreigners from migrating to Puerto Rico, it is easy to show that the IV estimates of the parameter $\beta_{2}$ would be positively biased. Hence the negative coefficients reported in Table 6 may underestimate the response elasticity.

\section{Simulating the Wage Effects of Labor Flows}

I now use the regression coefficients estimated above to simulate how the labor inflows and outflows altered the Puerto Rican wage structure. Suppose the estimated coefficient in a regression of the log weekly age on the in-migrant share is $\hat{\theta}_{1}$ and that the corresponding

coefficient on the out-migrant share is $\hat{\theta}_{2}$. Equation (7) then implies that the reduced-form impacts of an in-migration flow that shifts the supply of education group $i$ by $m_{i}$ percent and of an out-migration flow that shifts the supply by $x_{i}$ percent can be approximated by:

$$
\begin{aligned}
& \Delta \log w_{i}^{M}=\hat{\theta}_{1}(1-\bar{p})^{2} m_{i}, \\
& \Delta \log w_{i}^{X}=-\hat{\theta}_{2}(1-\bar{q})^{2} x_{i},
\end{aligned}
$$

where $\bar{p}$ and $\bar{q}$ are the mean values of the in-migrant and out-migrant shares observed in 2000 . To simulate the impact of the inflows and outflow observed in Puerto Rico between 1980 and 2000, I define the supply shocks as:

earned by native workers in the skill group. 


$$
m_{i}=\frac{M_{i, 2000}-M_{i, 1980}}{0.5\left(N_{i, 1980}+N_{i, 2000}\right)+M_{i, 1980}},
$$

$$
x_{i}=-\left(\frac{X_{i, 2000}-X_{i, 1980}}{0.5\left(N_{i, 1980}+N_{i, 2000}\right)+M_{i, 1980}}\right) \text {, }
$$

where $M_{i t}$ gives the number of in-migrants residing in Puerto Rico with education $i$ at time $t ; N_{i t}$ gives the number of Puerto Rican stayers; and $X_{i t}$ gives the number of Puerto Rican out-migrants residing in the United States. Note that the baseline population used to calculate the percent supply shifts in equations (10) and (11) averages the number of Puerto Rican stayers over the 1980-2000 period and treats the pre-existing immigrant population as part of the "native" stock. By definition, the variable $m_{i}$ is a positive number if in-migration increases the supply of workers in Puerto Rico, and $x_{i}$ is a negative number if out-migration results in a net outflow of Puerto Rican-born workers from Puerto Rico.

Table 7 summarizes the results of the simulation. Consider the evidence summarized in the top panel of the table, which use the OLS wage elasticities estimated separately for inmigration and out-migration and are reported in Model 1 of Table 5. The wage elasticity associated with in-migration is approximately -0.4 , while the wage elasticity associated with out-migration is -0.2 .

As columns 1 and 2 of Table 7 show, in-migration increased the number of workers in the Puerto Rican labor market by 10.6 percent, and out-migration reduced the number by 19.2 percent. This flow of in-migrants lowered wages by 4.2 percent, while the out-migrant flow 
increased wages by 3.8 percent (see columns 3 and 4). On aggregate, therefore, labor flows had only a negligible impact on the average Puerto Rican wage.

This result, however, masks a lot of variation across education groups. In particular, the supply shifts differ substantially by skill. Although the supply of the least-educated workers (high school graduates with 0-8 years of schooling) was barely affected by in-migration, the number of workers with more than a high school diploma rose by around 15 percent. Similarly, the out-migration of highly educated workers reduced the number of workers in those skill groups by 40 to 50 percent. However, net flows of Puerto Rican-born workers between the United States and Puerto Rico actually increased the supply of the least-educated workers in Puerto Rico! The direction of the net flow of low-educated Puerto Rican-born workers flowed from the United States to Puerto Rico between 1980 and 2000. As a result, the process of "outmigration" increased the size of the low-skill workforce in Puerto Rico by 25 to 50 percent.

Inevitably, these very different supply shifts had very different wage effects. Consider, for example, the wage impact of in-migration. The wage of the least-educated workers (i.e., high school dropouts with 0-8 years of schooling) is barely affected by in-migration, while the 19802000 in-migrant influx is predicted to have reduced the wage of college-educated workers by almost 6 percent.

The differences are much larger in the predicted impact of out-migration. The flow of Puerto Rican-born workers between Puerto Rico and the United States lowered the wage of the least-educated workers by 5 to 10 percent, but raised the wage of the most educated workers by 8 to 10 percent. In other words, the two-way flow of Puerto Rican-born workers had a substantial 
impact on the wage gap across skill groups, increasing the relative wage of college graduates by at least 15 percent. ${ }^{26}$

The bottom panel of the table replicates the simulation exercise using the wage elasticity estimated in the regression reported in Model 2 of Table 4, which uses the net migrant share as the independent variable. This specification constrains the wage elasticity to be the same for both in-migration and out-migration. It is evident that the qualitative nature of the empirical evidence is unaffected.

Finally, Column 5 of Table 7 adds the predicted wage effects of in-migration and outmigration to calculate the net impact of all labor flows on the Puerto Rican wage structure (while column 6 reports what actually happened to the real wage of the various skill groups). In rough terms, the wage impact of the opposing flows of highly educated workers (foreign-born college graduates migrating in at the same time that Puerto Rican-born college graduates migrate out to the United States) either wash out or result in a slight positive gain. In contrast, the wage impact of the various labor flows on the wage of low-skill Puerto Ricans works in the same direction, resulting in a sizable decline in the relative wage of this group. In the end, the sizable labor flows that were a key feature of the Puerto Rican labor market during the 1980s and 1990s reduced the relative wage of low-skill workers, perhaps by as much as 15 to 20 percent.

\footnotetext{
26 The ultimate effect of migration on absolute wage levels depends on how capital flows respond to the labor supply shifts. Under some separability assumptions, the relative wage impact on different education groups is the same regardless of the extent of capital adjustment. For example, in the three-level CES framework introduced by Borjas (2003), the predicted wage effect for each skill group in the short and long runs differ only by a constant, so the relative wage effect of the labor flows can be easily calculated by simply differencing the group-specific wage effects.
} 


\section{Summary}

One of the central questions in the economics of migration concerns the impact of migrants on the labor markets of sending and receiving areas. Economic theory suggests that, at least in the short run, migrant-induced shifts in labor supply should lead to opposite-signed changes in the wage of competing workers. This wage response is a crucial parameter not only in the study of the efficiency and distributional impact of migration, but also in the policy debate over how to best regulate the population flows.

Puerto Rico presents a unique laboratory for testing these implications of economic theory—-for it has both large inflows and outflows of workers. The immigrant population in Puerto Rico now makes up around 14 percent of its male workforce. Put differently, immigration into Puerto Rico is as important a demographic phenomenon as it is in the United States. However, in contrast to the United States (and other immigrant-receiving countries), nearly 40 percent of the potential male workforce has left the island and lives in the United States.

Using data drawn from the microdata censuses of Puerto Rico and the United States, this paper examines the determinants and consequences of these labor flows. The empirical analysis documented a number of findings. First, the in-migrants and the out-migrants differ significantly in their skill composition. In particular, at least until recently, in-migrants tend to be relatively skilled and out-migrants tend to be relatively unskilled. This difference helps to resolve the question of how sizable inflows and outflows can coexist if all migrants are income maximizers. The answer is clear: the types of workers flowing in one direction are almost the opposite (in terms of their skills) as the types flowing in the other direction. In the end, all migrants make a sensible human capital investment, but they collect the returns in different places. 
The study also documented that inflows and outflows have opposing effects on the Puerto Rican wage structure. Immigrants tend to reduce wages, and out-migrants tend to increase wages. The numerical response to these opposing flows was roughly the same: a 10 percent labor supply shift is associated with about a 2 to 4 percent opposite-signed change in wages. These wage shifts are sufficiently large for migration flows to have a numerically important impact on the Puerto Rican wage structure. If the wage elasticity were on the order of -0.3 , a net outmigration of 30 percent would, by itself, increase the average Puerto Rican wage by nearly 10 percent - implying that labor flows played an important role in the narrowing of the income gap between Puerto Rico and the United States. 


\section{DATA APPENDIX}

\section{Puerto Rico}

The data are drawn from the 1970, 1980, 1990, and 2000 Public Use Samples of the Puerto Rican Census. The 1970 Census extract forms a 3 percent sample (obtained by pooling the state, municipal, and neighborhood files). The 1980-2000 Census extracts form a 5 percent sample. The analysis is restricted to men aged 14-64. A person is classified as a native-born Puerto Rican if he was born in Puerto Rico. He is classified as an in-migrant from the United States if he was born in the United States; and he is classified as an in-migrant from other countries he if he was born in other countries. Sampling weights are used in all calculations.

Definition of education and experience: I convert the Census-provided education variables into the IPUMS recoded variable educrec using the code provided by the Minnesota Population Center. The workers are classified into five education groups as follows: high school dropouts with 0 to 8 years of schooling $(e d u c r e c \leq 3)$, high school dropouts with 9 to 11 years of schooling $(4 \leq$ educrec $\leq 6)$, high school graduates $($ educrec $=7)$, persons with some college $($ educrec $=8)$, and college graduates $($ educrec $=9)$. I assume that high school dropouts with 0-8 years of schooling enter the labor market at age 14; high school dropouts with 9-11 years of schooling at age 16, high school graduates at age 19, persons with some college at age 21 , and college graduates at age 23 and define work experience as the worker's age at the time of the survey minus the assumed age of entry into the labor market. I restrict the analysis to persons who have between 1 and 40 years of experience. Workers are classified into one of 4 experience groups, defined in ten-year intervals. 
Counts of persons in education-experience groups: The counts are calculated in the sample of men who worked at some point in the past year (i.e., have a positive value for weeks worked in the calendar year).

Annual and weekly earnings: I use the sample of men who reported positive annual earnings and weeks worked, are not in the military in the reference week, are not enrolled in school, and are aged 18-64. The measure of earnings is the sum of the IPUMS variables incearn, incbus, and incfarm in 1970 and 1980, and is given by incearn in 1990-2000. In the 1970 and 1980 Censuses, the top coded annual salary is multiplied by 1.5. In the 1970 Census, weeks worked in the calendar year prior to the survey are reported as a categorical variable. I imputed weeks worked for each worker as follows: 6.5 weeks for 13 weeks or less, 20 for 14-26 weeks, 33 for $27-39$ weeks, 43.5 for $40-47$ weeks, 48.5 for $48-49$ weeks, and 51 for $50-52$ weeks. The average log annual earnings or average log weekly earnings for a particular education-experience cell is defined as the mean of log annual earnings or log weekly earnings over all workers in the relevant population.

Fraction of time worked: This variable is calculated in the sample of men. The fraction of time worked for each person is defined as the ratio of weeks worked (including zeros) to 52 .

\section{United States}

The data are drawn from the 1970, 1980, 1990, and 2000 Integrated Public Use Microdata Samples (IPUMS) of the U.S. Census. The 1970 Census extract forms a 3 percent sample (obtained by pooling the state, metropolitan area, and neighborhood files). The 19802000 Census extracts form a 5 percent sample. The analysis is restricted to men aged 14-64. A person is classified as a Puerto Rican out-migrant if he was born in Puerto Rico. A person is 
classified as U.S.-born of Puerto Rican ancestry if he was born in the United States and is Hispanic of Puerto Rican background (hispand $=200$ ). Sampling weights are used in all calculations.

Definition of education and experience: I use the IPUMS variable educrec to first classify workers into five education groups: high school dropouts with 0-8 years of schooling (educrec $<=3$ ), high school dropouts with 9-11 years of schooling $(4 \leq$ educrec $\leq 6)$ high school graduates $($ educrec $=7)$, persons with some college $($ educrec $=8)$, and college graduates $($ educrec $=9)$. I assume that age of entry into the labor market is 14 for high school dropouts with less than 8 years of schooling, 16 for high school dropouts with 9-11 years of schooling, 18 for high school graduates, 21 for persons with some college, and 23 for college graduates, and define work experience as the worker's age at the time of the survey minus the assumed age of entry into the labor market. I restrict the analysis to persons who have between 1 and 40 years of experience. Workers are classified into one of 4 experience groups, defined in ten-year intervals. Counts in education-experience groups: The counts of out-migrants are calculated in the sample of Puerto Rican-born men who do not reside in group quarters and worked at some point in the past year (i.e., have a positive value for weeks worked in the period calendar year). 


\section{References}

Altonji, Joseph G. and Card, David. 1991. The Effects of Immigration on the Labor Market Outcomes of Less-Skilled Natives. In Immigration, Trade, and the Labor Market, ed. John M. Abowd and Richard B. Freeman. Chicago: University of Chicago Press.

Aydemir, Abdurrahman, and George J. Borjas. 2007. Cross-Country Variation in the Impact of International Migration: Canada, Mexico, and the United States. Journal of the European Economic Association 5, no. 4: 663-708.

Blanchard, Olivier Jean, and Lawrence F. Katz. 1992. Regional Evolutions. Brookings Papers on Economic Activity, no. 1: 1-75.

Bonin, Holger. 2005. Is the Demand Curve Really Downward Sloping? Working Paper No. 1875, IZA, Bonn, Germany.

Borjas, George J. 1987. Self-Selection and the Earnings of Immigrants. American Economic Review 77, no. 4: 531-553.

Borjas, George J. 2003. The Labor Demand Curve Is Downward Sloping: Reexamining the Impact of Immigration on the Labor Market. Quarterly Journal of Economics 118, no. 4: 1335-1374.

Borjas, George J. 2006. Native Internal Migration and the Labor Market Impact of Immigration. Journal of Human Resources 41, no. 2: 221-258.

Borjas, George J., Richard B. Freeman, and Lawrence F. Katz. 1997. How Much Do Immigration and Trade Affect Labor Market Outcomes? Brookings Papers on Economic Activity, no. 1: 1-67.

Card, David. 1991. The Impact of the Mariel Boatlift on the Miami Labor Market. Industrial and Labor Relations Review 43, no. 2: 245-257.

Card, David. 2001. Immigrant Inflows, Native Outflows, and the Local Labor Market Impacts of Higher Immigration. Journal of Labor Economics 19, no. 1: 22-64.

Card, David. 2005. Is the New Immigration Really So Bad? Economic Journal 115, no. 507: F300-F323.

Card, David, and Thomas Lemieux, 2001. Can Falling Supply Explain the Rising Return to College for Younger Men? A Cohort-Based Analysis. Quarterly Journal of Economics 116, no. 2: 705-746.

Chiquiar, Daniel, and Gordon H. Hanson. International Migration, Self-Selection, and the Distribution of Wages: Evidence from Mexico and the United States. Journal of Political Economy 113, no. 2: 239-281. 
Davis, Steven J., and Luis Rivera-Batiz. 2005. The Climate for Business Development and Employment Growth in Puerto Rico. Working Paper No. 11679, National Bureau of Economic Research, Cambridge, MA.

Enchautegui, Maria. 1993. The Value of U.S. Labor Market Experience in the Home Country: The Case of Puerto Rican Return Migrants. Economic Development and Cultural Change 42, no. 1: 169-191.

Enchautegui, Maria, and Richard B. Freeman. 2005. Why Don't Puerto Rican Men Work? The Rich Uncle (Sam) Hypothesis. Working Paper No.11751, National Bureau of Economic Research, Cambridge, MA.

Fernández-Huertas Moraga, Jesus. 2006. New Evidence on Emigrant Selection. Working Paper, Columbia University, New York.

Fitzpatrick, Joseph P. 1980. Puerto Ricans. In Harvard Encyclopedia of American Ethnic Groups, ed. Stephan Thernstrom. Cambridge, MA: Harvard University Press.

Friedberg, Rachel M., and Jennifer Hunt. 1995. The Impact of Immigration on Host Country Wages, Employment and Growth. Journal of Economic Perspectives 9, no. 2: 23-44.

Greenwood, Michael J. 1997. Internal Migration in Developed Countries. In Handbook of Population and Family Economics, Volume 1B, ed. Mark R. Rosenzweig and Oded Stark. Amsterdam: Elsevier.

Hernandez Alvarez, Jose. 1967. Return Migration to Puerto Rico. Berkeley, CA: University of California Institute of International Studies.

Hicks, John R. 1932. The Theory of Wages. London: Macmillan.

Heston, Alan, Robert Summers, and Bettina Aten. 2006. Penn World Table Version 6.2. Center for International Comparisons of Production, Income and Prices, Philadelphia, PA.

Ibarrarán, Pablo, and Darren Lubotsky. 2007. Mexican Immigration and SelfSelection: New Evidence from the 2000 Mexican Census. In Mexican Immigration to the United States, ed. George J. Borjas. Chicago: University of Chicago Press, 2007, pp. 159-192.

LaLonde, Robert J., and Robert H. Topel. 1991. Labor Market Adjustments to Increased Immigration. In Immigration, Trade, and the Labor Market, ed. John M. Abowd and Richard B. Freeman. Chicago: University of Chicago Press.

Mishra, Prachi. 2007. Emigration and Wages in Source Countries: Evidence from Mexico. Journal of Development Economics 82, no. 1: 180-199. 
Muschkin, Clara G. 1993. Consequences of Return Migrant Status for Employment in Puerto Rico. International Migration Review 27, no. 1: 79-102.

Ramos, Fernando. 1992. Out-Migration and Return Migration of Puerto Ricans. In Immigration and the Work Force: Economic Consequences for the United States and Source Areas, ed. George J. Borjas and Richard B. Freeman. Chicago: University of Chicago Press.

Sjaastad, Larry. 1962. The Costs and Returns of Human Migration, Journal of Political Economy 70, no. 5, part 2: 80-93.

Welch, Finis. 1979. Effects of Cohort Size on Earnings: The Baby Boom Babies' Financial Bust. Journal of Political Economy 87, no. 5, part 2: S65-S97. 
Figure 1. Trends in in-migrant and out-migrant shares in the population

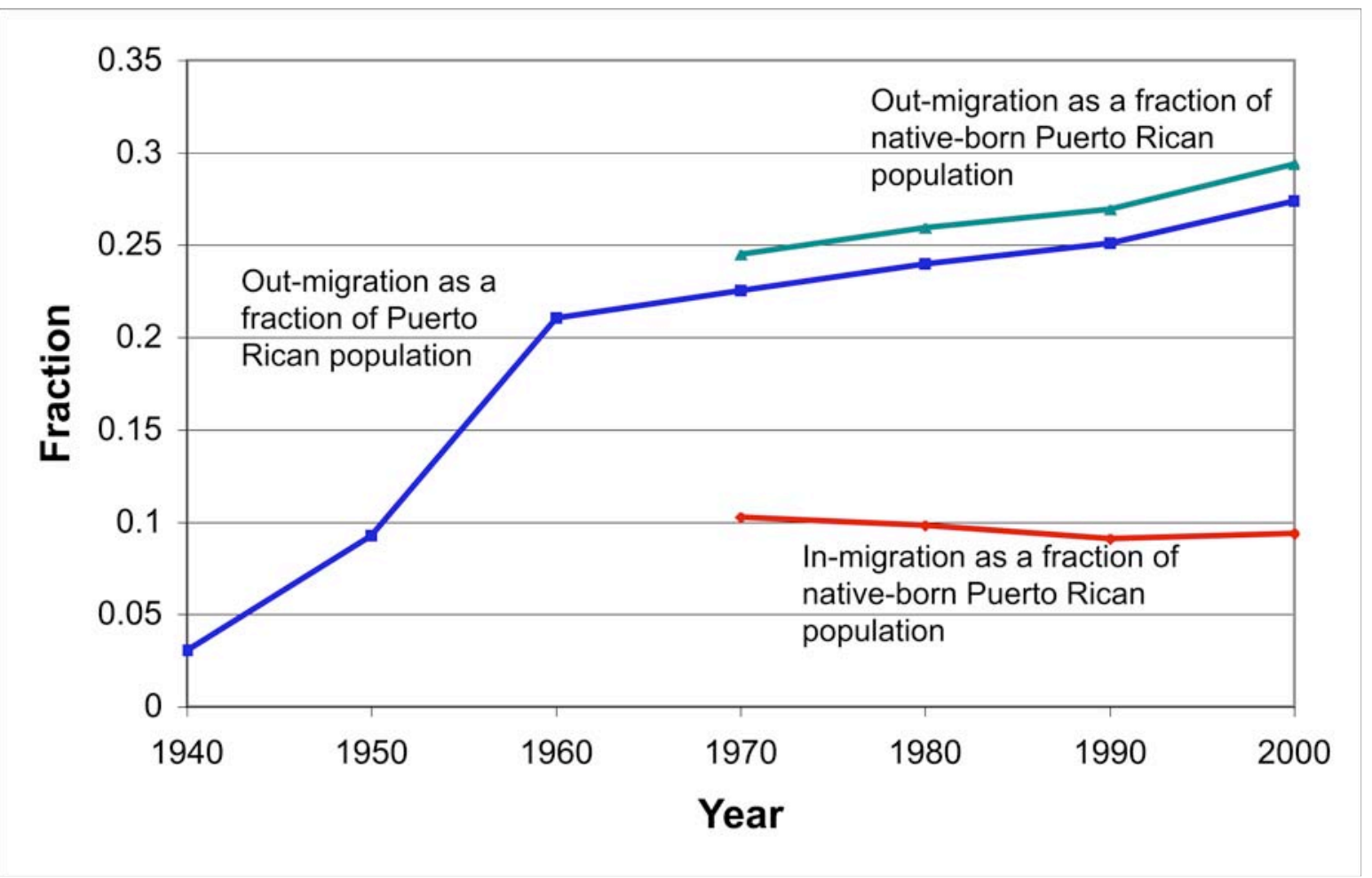

Notes: An out-migrant is a person born in Puerto Rico, but residing in the United States; an in-migrant is a person born outside Puerto Rico, but residing in Puerto Rico. The 1940-2000 out-migration series is defined by the ratio of the number of out-migrants to the Puerto Rican population at a point in time. The denominator in the 1970-2000 inmigrant and out-migrant series is the total number of Puerto Rican born persons (i.e., the sum of Puerto Rican born persons enumerated in both Puerto Rico and the United States). All statistics are based on calculations that use the entire population counts. 
Figure 2. Per-capita GDP of Puerto Rico (relative to U.S.)

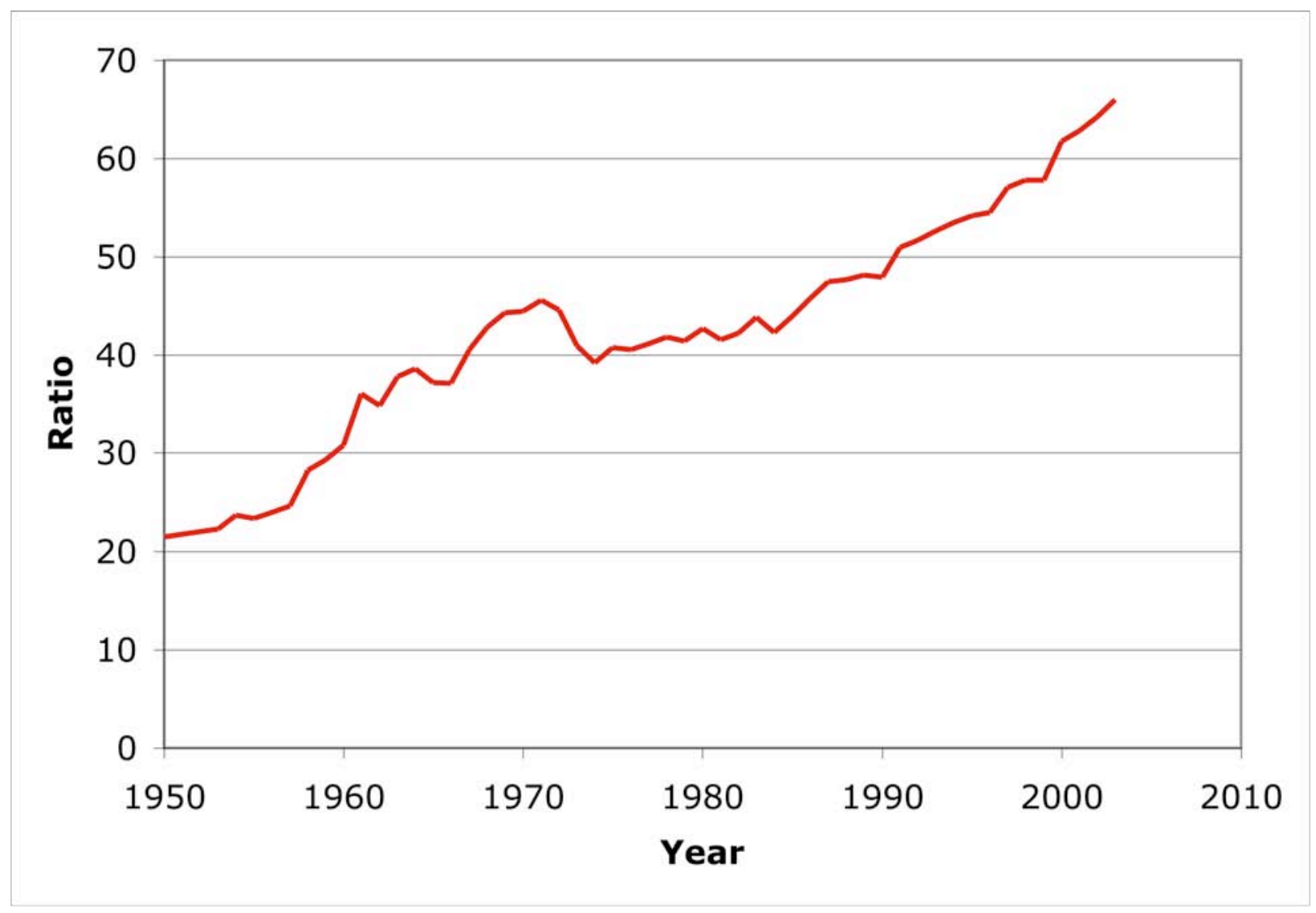

Source: Heston, Summers, and Aten (2006), The ratio of per capita GDP is based on GDP estimates that are adjusted for international prices. The 1950-2003 series is obtained by splicing the 1950-1969 estimates from version 6.1 of the Penn World Tables with the post-1970 estimates from version 6.2. 
Figure 3. Out-migrant and in-migrant shares for working men

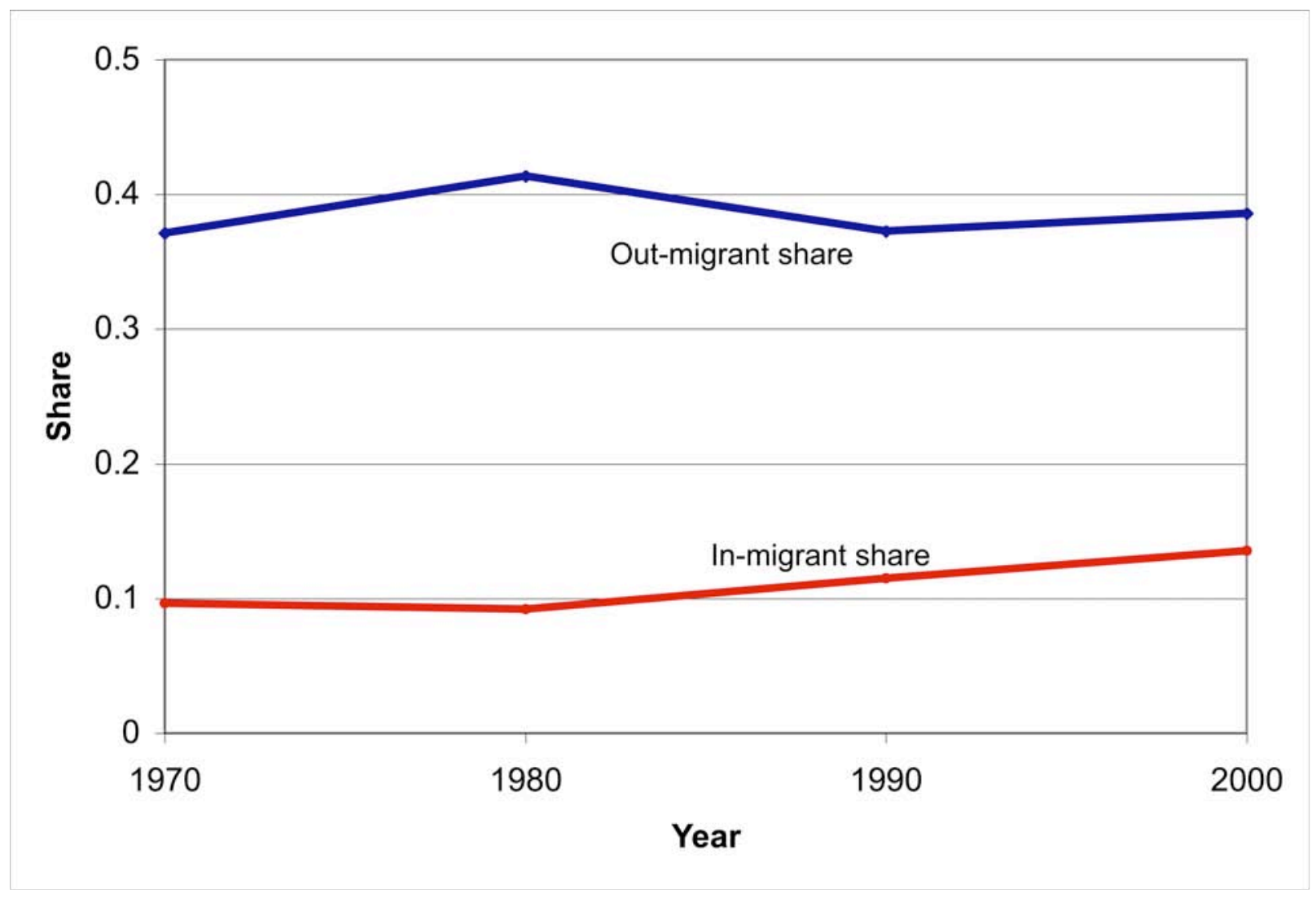

Notes: The out-migrant share gives the ratio of the number of out-migrant working men to the potential number of Puerto Rican-born working men (defined as the sum of the number of out-migrants plus the number of Puerto Rican stayers); the in-migrant share gives the ratio of the number of in-migrants working men to the number of working men in the Puerto Rican workforce (defined as the sum of the number of in-migrants plus the number of Puerto Rican stayers). 
Figure 4. Out-migrant shares of Puerto Rican-born population, by education

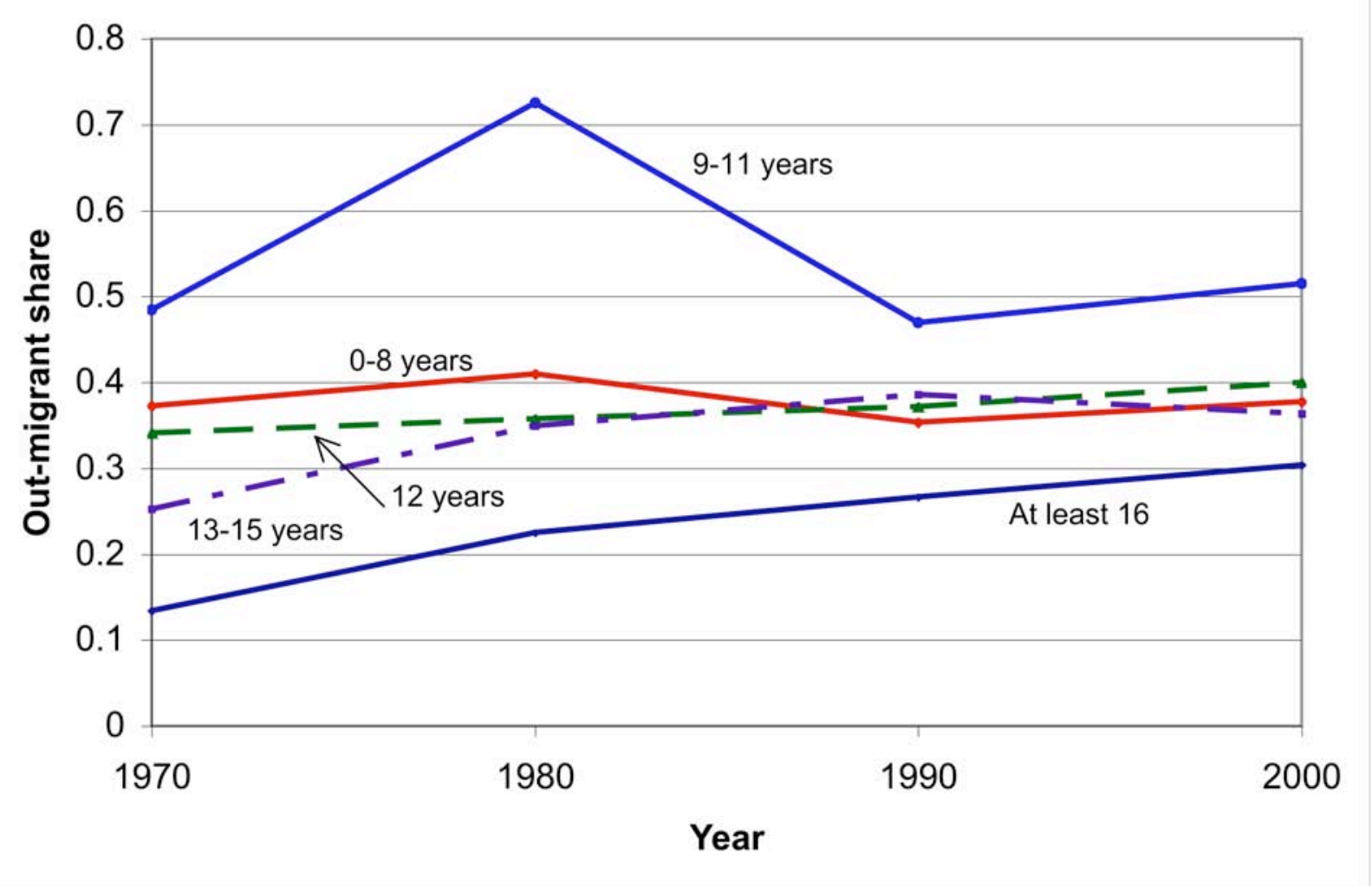

Notes: The out-migrant share gives the ratio of the number of out-migrant working men to the potential number of Puerto Rican-born working men (defined as the sum of the number of out-migrants plus the number of Puerto Rican stayers). 
Figure 5. Out-migrant share of U.S.-born persons to Puerto Rico (relative to the number of U.S.-born persons of Puerto Rican ancestry)

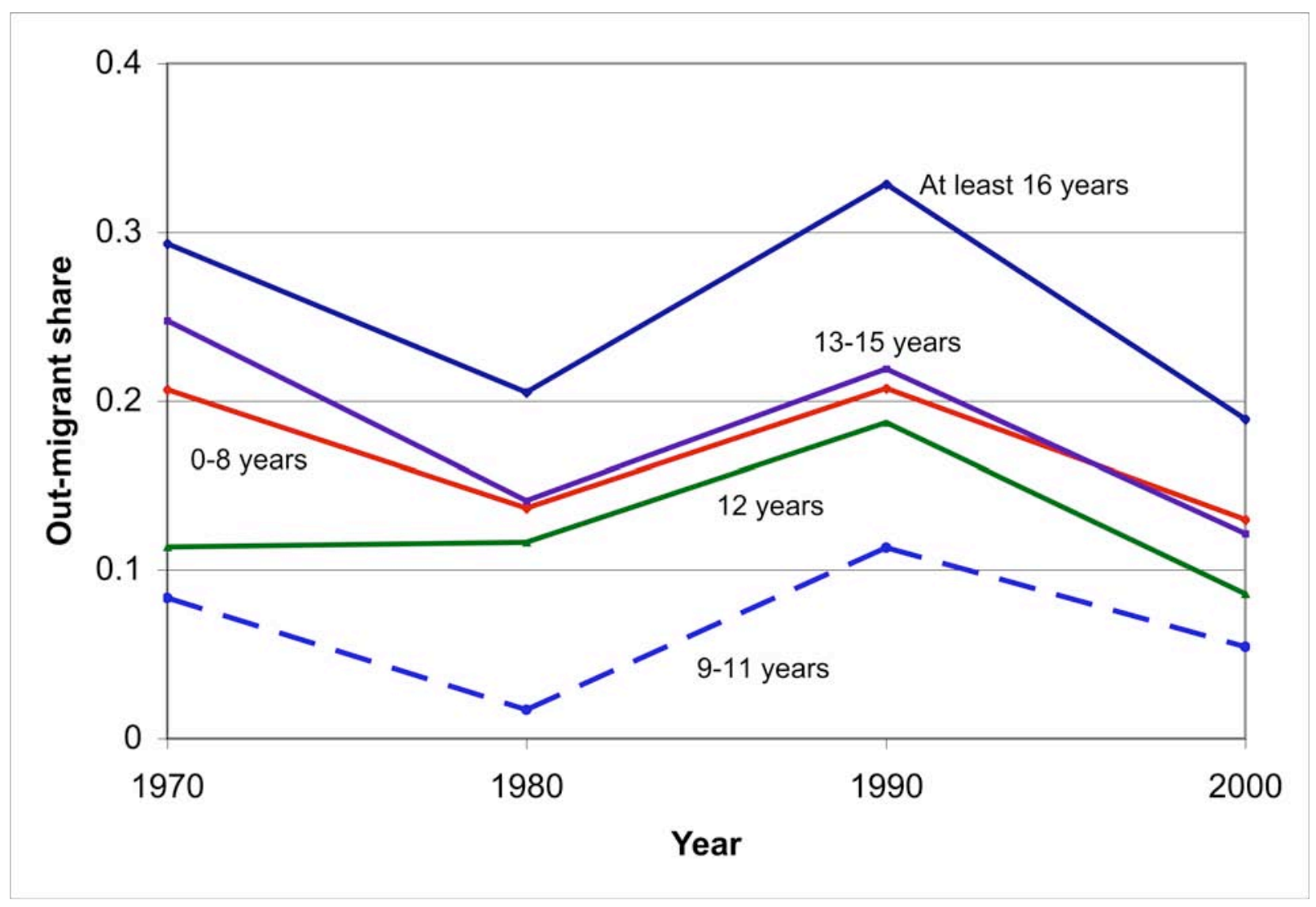

Notes: The out-migrant share gives the ratio of the number of U.S.-born out-migrants to Puerto Rico to the potential number of U.S.-born persons of Puerto Rican ancestry (defined as the sum of the number of out-migrants plus the number of U.S.-born persons of Puerto Rican ancestry who stayed in the United States). 
Figure 6. In-migrants in Puerto Rico, as a fraction of the Puerto Rican-born population, by education

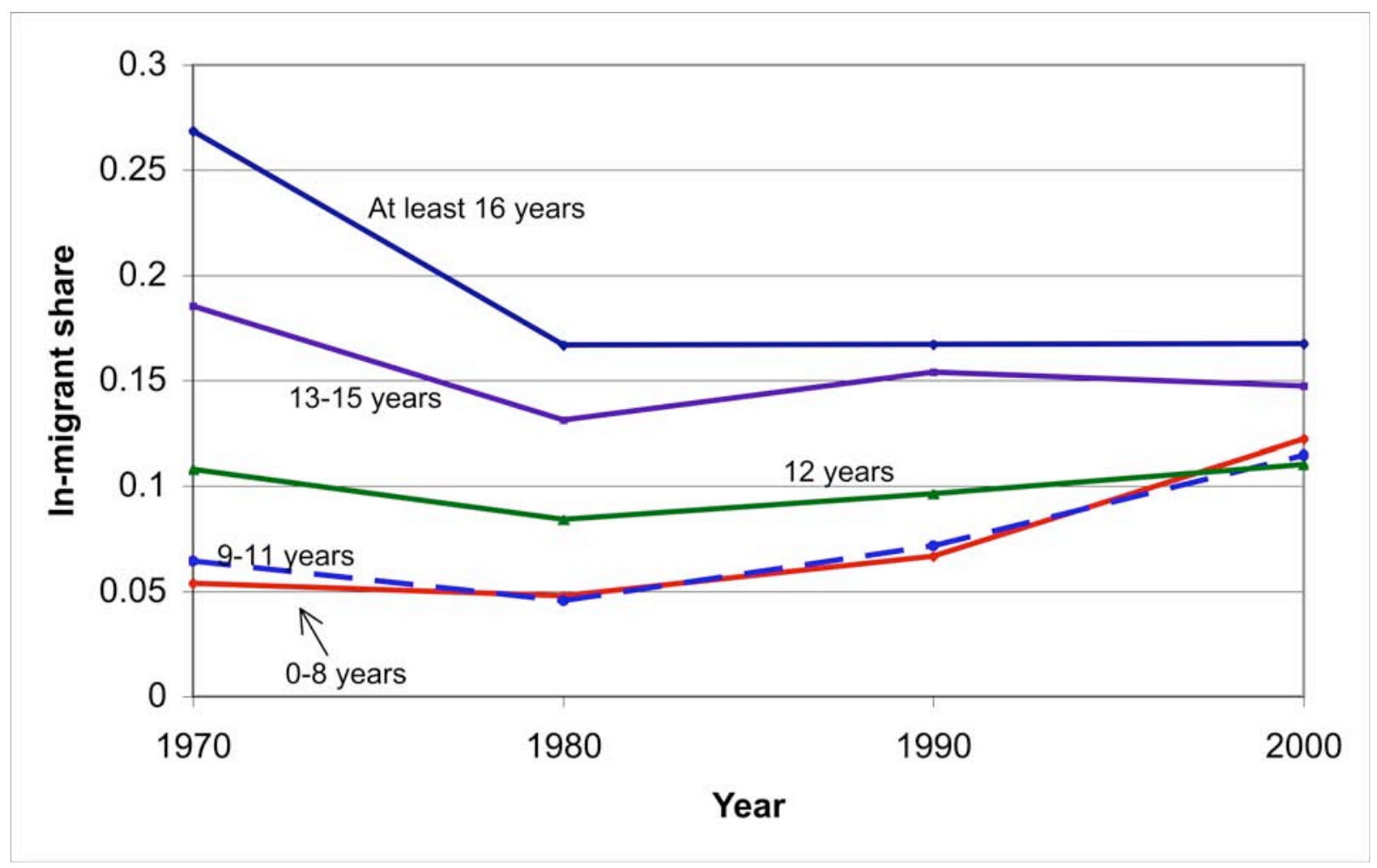

Notes: The in-migrant share gives the ratio of the number of in-migrants working men to the number of working men in the Puerto Rican workforce (defined as the sum of the number of in-migrants plus the number of Puerto Rican stayers). 
Figure 7 - The out-migrant share in Puerto Rico, 1970-2000

High school dropouts, 0-8
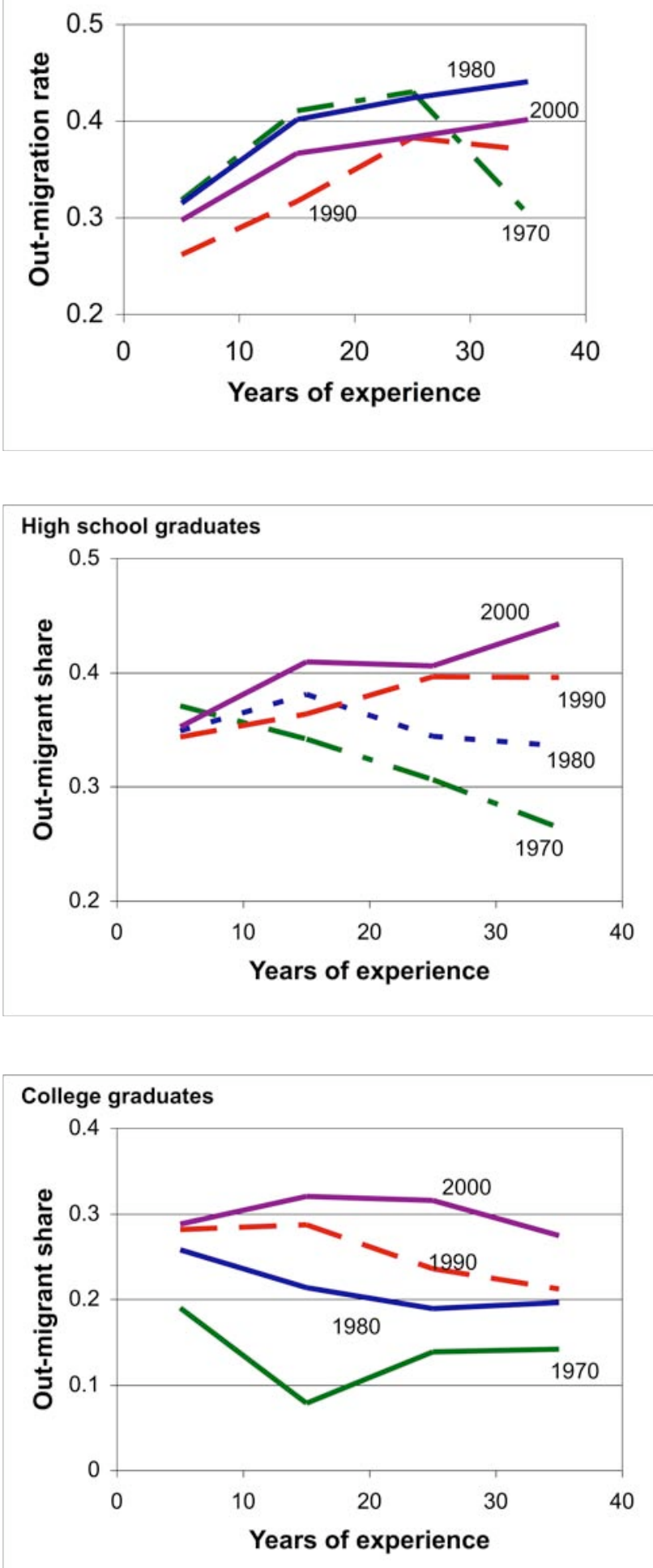

Note: The out-migrant share gives the ratio of the number of out-migrant working men to the potential number of Puerto Rican-born working men.
High school dropouts, 9-11
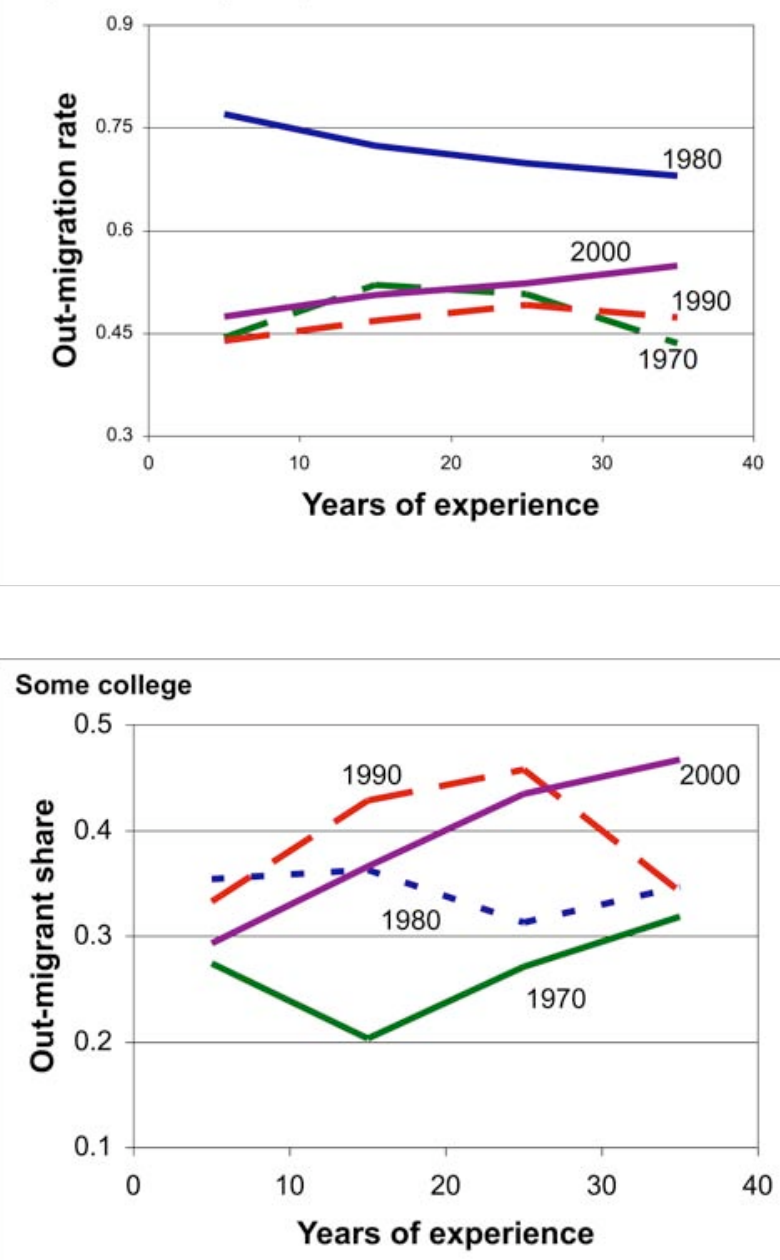
Figure 8 - The in-migrant share in Puerto Rico, 1970-2000

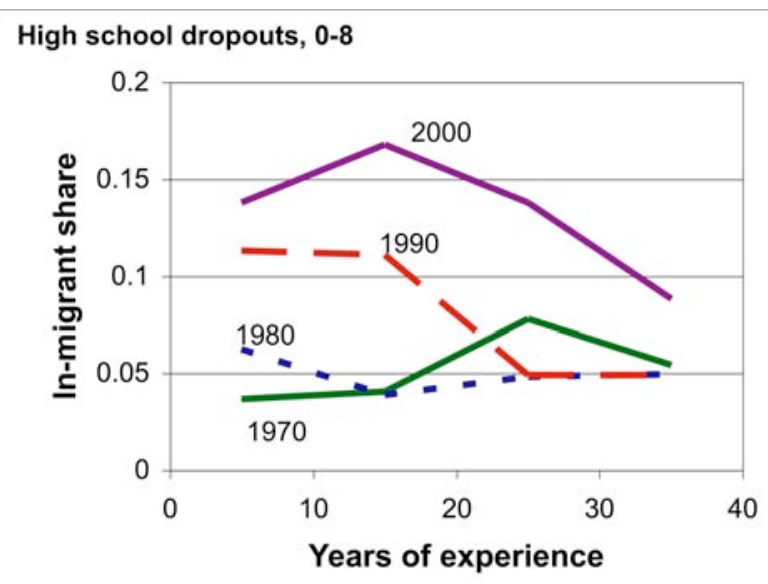

High school dropouts, 9-11
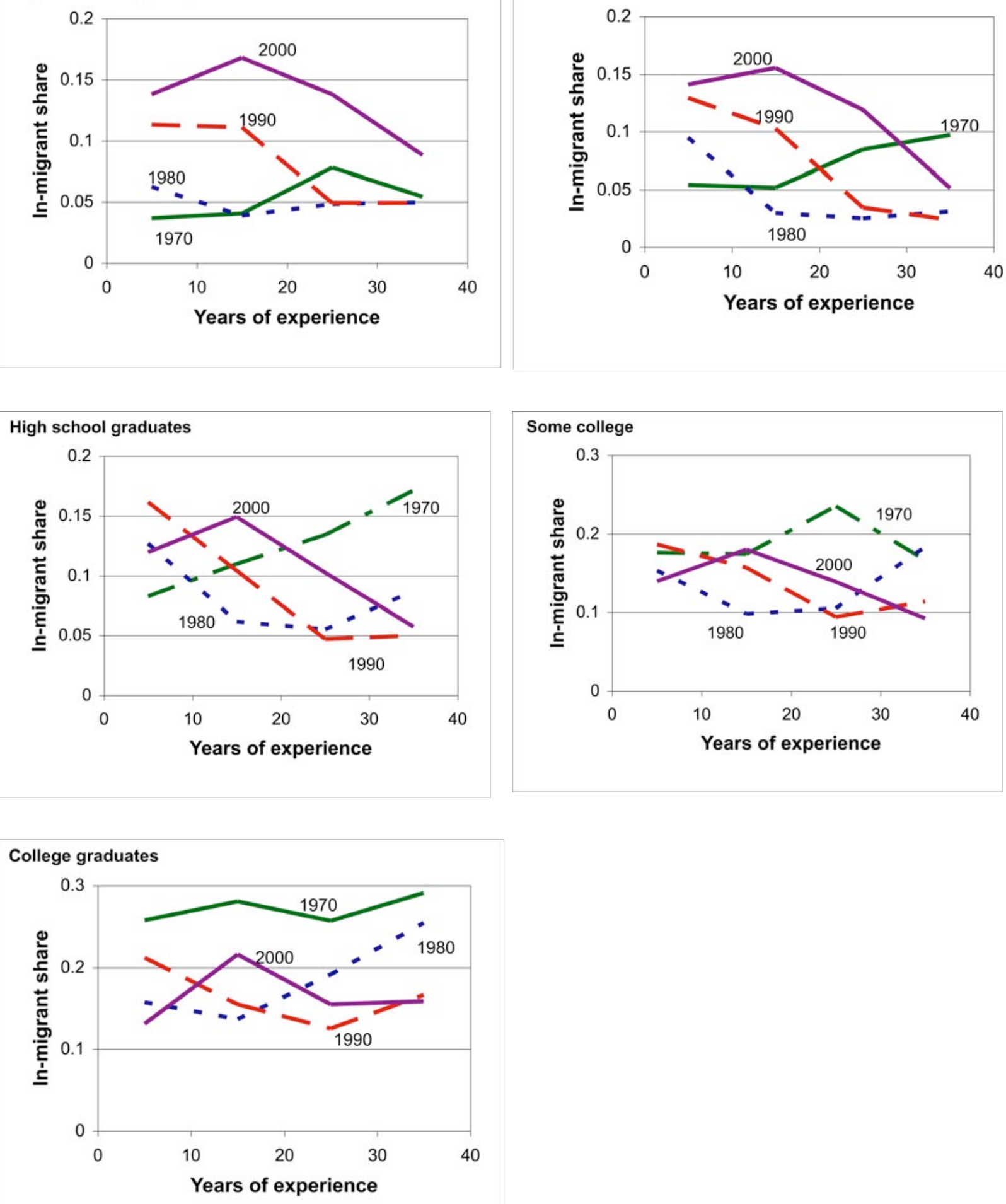

Note: The in-migrant share gives the ratio of the number of out-migrant working men to the potential number of Puerto Rican-born working men. 
Figure 9. Relation between in-migrant and out-migrant shares

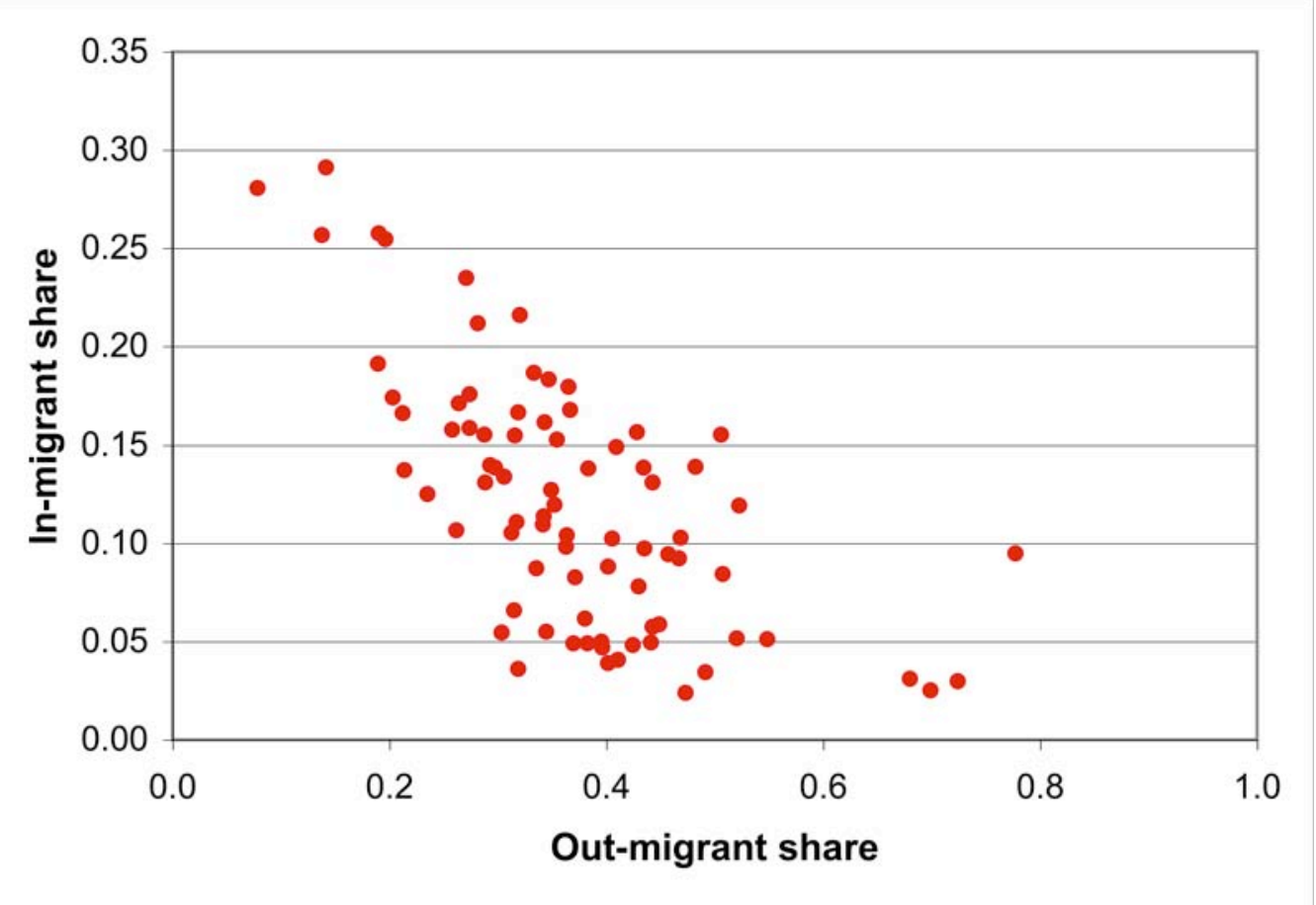

Notes: The out-migrant share gives the ratio of the number of out-migrant working men to the potential number of Puerto Rican-born working men (defined as the sum of the number of out-migrants plus the number of Puerto Rican stayers); the in-migrant share gives the ratio of the number of in-migrants working men to the number of working men in the Puerto Rican workforce (defined as the sum of the number of in-migrants plus the number of Puerto Rican stayers). 


\section{Table 1. National origin of inflows into Puerto Rico}

Percent of population born outside Puerto Rico

\begin{tabular}{cccc}
1970 & 1980 & 1990 & 2000 \\
\hline $10.3 \%$ & $9.8 \%$ & $9.1 \%$ & $9.4 \%$
\end{tabular}

Percent of foreign-born population in Puerto Rico born in:

United States

$73.0 \quad 80$

Colombia

0.6

80.1

75.2

69.3

Cuba

9.4

0.6

0.7

1.0

Dominican Republic

4.5

7.2

6.0

5.5

Spain

1.7

6.5

11.1

17.1

1.7

1.1

1.1

Percent of U.S.-born population living in Puerto Rico

47.3

80.7

88.8

80.0 that has Puerto Rican ancestry

Source: Calculations from the 1970, 1980, 1990, and 2000 Puerto Rican censuses. All statistics are based on enumerations from the entire population counts. 


\section{Table 2. Summary characteristics of spread of male wage distributions In Puerto Rico and the United States}

\begin{tabular}{|c|c|c|c|c|}
\hline \multirow{2}{*}{\multicolumn{5}{|c|}{ Puerto Rico }} \\
\hline & & & & \\
\hline Variance of log weekly earnings & 0.713 & 0.701 & 0.883 & 0.727 \\
\hline Residual variance of log weekly earnings & 0.559 & 0.541 & 0.710 & 0.569 \\
\hline $\begin{array}{l}\text { Experience-adjusted log weekly earnings } \\
\text { differential between college graduates and } \\
\text { workers with } 8-11 \text { years of schooling }\end{array}$ & 1.066 & 1.066 & 1.055 & 1.055 \\
\hline $\begin{array}{l}\text { Experience-adjusted log weekly earnings } \\
\text { differential between college and high } \\
\text { school graduates }\end{array}$ & 0.807 & 0.760 & 0.811 & 0.847 \\
\hline \multicolumn{5}{|l|}{ United States } \\
\hline Variance of log weekly earnings & 0.542 & 0.615 & 0.655 & 0.710 \\
\hline Residual variance of log weekly earnings & 0.414 & 0.477 & 0.480 & 0.533 \\
\hline $\begin{array}{l}\text { Experience-adjusted log weekly earnings } \\
\text { differential between college graduates and } \\
\text { workers with } 8-11 \text { years of schooling }\end{array}$ & 0.747 & 0.726 & 0.957 & 1.018 \\
\hline $\begin{array}{l}\text { Experience-adjusted log weekly earnings } \\
\text { differential between college and high } \\
\text { school graduates }\end{array}$ & 0.527 & 0.444 & 0.623 & 0.683 \\
\hline
\end{tabular}

Notes: The calculations in the Puerto Rican Census use the sample of Puerto Rican-born working men aged 18-64, and the calculations in the U.S. Census use the sample of U.S.-born working men aged 18-64. 
Table 3. Determinants of out-migrant share in Puerto Rico (Dependent variable $=$ Decadal change in out-migrant share of Puerto Rican-born workers from Puerto Rico)

Variables:

Specification

Panel A: $w^{U S}=$ wage of Puerto Rican immigrants in U.S.

$\Delta\left(w^{U S}-w^{P R}\right)$

0.098

0.147

$(0.041)$

$(0.111)$

$\Delta w^{U S}$

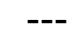

$---$

0.026

0.151

$\Delta w^{P R}$

$--$

$---$

$(0.067)$

$-0.109$

$(0.105)$

(0.048)

$-0.133$

$(0.233)$

Panel B: $w^{U S}=$ wage of native workers in U.S.

$\Delta\left(w^{U S}-w^{P R}\right)$

$\begin{array}{cc}0.120 & 0.188 \\ (0.039) & (0.069)\end{array}$

$\Delta w^{U S}$

(-)

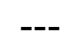

0.661

0.563

$\Delta w^{P R}$

$---$

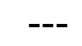

(0.206)

$-0.173$

$-0.279$

(0.068)

$(0.257)$

Panel C: $w^{U S}=$ wage of Puerto Rican immigrants in N.Y.

$\Delta\left(w^{U S}-w^{P R}\right)$

$\Delta w^{U S}$

$\Delta w^{P R}$

Controls for period fixed effects

$$
0.078
$$

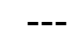

$---$

No
0.297

(0.134)
$-0.061$

(0.093)

$-0.095$

(0.046)
0.313

(0.115)

$-0.256$

(0.246)

No

Yes

Notes: Standard errors are reported in parentheses and are adjusted for clustering within education-experience cells. All regressions are weighted by the sum of sampling weights in the cell. The regressions have 60 educationexperience-year cells. The out-migrant share gives the ratio of the number of working men who left Puerto Rico to the potential number of Puerto Rican-born working men. The potential wage in Puerto Rico is given by the average wage of Puerto Rican stayers. The " $\Delta$ " operator for the regressors indicates that these variables are defined as decadal changes. 
Table 4. Determinants of out-migrant share of U.S.-born workers (Dependent variable $=$ Decadal change in out-migrant share of U.S.-born Puerto Ricans from the U.S.)

Variables:

\begin{tabular}{llll}
\multicolumn{4}{c}{ Specification } \\
\hline 1 & 2 & 3 & 4 \\
\hline
\end{tabular}

Panel A: $w^{U S}=$ wage of Puerto Ricans in U.S. $\Delta\left(w^{U S}-w^{P R}\right)$

$-0.148$

(0.050)

$\Delta w^{U S}$

$\Delta w^{P R}$

$(0.042)$

(0.042)

$\begin{array}{ll}--- & --- \\ --- & -- \\ & \\ & \\ .176 & -0.036 \\ 047) & (0.048)\end{array}$

Panel B: $w^{U S}=$
$\Delta\left(w^{U S}-w^{P R}\right)$

--- ---

$\Delta w^{U S}$

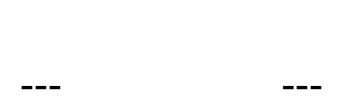

$\Delta w^{P R}$

$\begin{array}{cc}--- & 0.177 \\ & (0.050)\end{array}$
$-0.483$
$(0.294)$
0.177

(0.262)

0.146

(0.056)

$-0.296$

0.026

$(0.245)$

0.042

(0.046)

Panel C: $w^{U S}=$ wage of Puerto Ricans in N.Y. $\Delta\left(w^{U S}-w^{P R}\right)$ $\begin{array}{ll}-0.096 & -0.078 \\ (0.044) & (0.037)\end{array}$

$\Delta w^{U S}$

$--$

0.339

(0.125)

0.087

$-0.291$

(0.116)

(0.049)

$(0.045)$

Controls for period fixed effects

No

Yes

No

Yes

Notes: Standard errors are reported in parentheses and are adjusted for clustering within education-experience cells. All regressions are weighted by the sum of sampling weights in the cell. The regressions have 60 educationexperience-year cells. The out-migrant share gives the ratio of the number of U.S.-born workers in Puerto Rico to the potential number of U.S.-born persons of Puerto Rican ancestry. The potential wage in Puerto Rico is given by the average wage of U.S.-born immigrants in Puerto Rico. The " $\Delta$ " operator for the regressors indicates that these variables are defined as decadal changes. 


\section{Table 5. Relation between labor flows and labor market outcomes}

\begin{tabular}{cccc} 
& \multicolumn{3}{c}{ Dependent variable } \\
\cline { 2 - 4 } Specification & $\begin{array}{c}\text { Decadal change in } \\
\text { log annual earnings }\end{array}$ & $\begin{array}{c}\text { Decadal change in } \\
\text { log weekly earnings }\end{array}$ & $\begin{array}{c}\text { Decadal change in } \\
\text { fraction of weeks worked }\end{array}$ \\
\cline { 2 - 4 }$\Delta$ (In-migrant share) & -0.631 & -0.543 & -0.243 \\
& $(0.246)$ & $(0.269)$ & $(0.187)$ \\
$\Delta$ (Out-migrant share) & 0.678 & 0.537 & 0.250 \\
& $(0.246)$ & $(0.185)$ & $(0.153)$ \\
Model 2 & & & \\
$\Delta$ (Net migrant share) & -0.665 & -0.539 & -0.248 \\
& $(0.175)$ & $(0.165)$ & $(0.090)$
\end{tabular}

Notes: Standard errors are reported in parentheses and are adjusted for clustering within education-experience cells. All regressions are weighted by the sum of sampling weights in the skill cell and have 60 education-experience-year cells. The out-migrant share gives the ratio of the number of out-migrants to the potential number of Puerto Ricanborn working men, and the in-migrant share gives the ratio of the number of in-migrants to the number of working men in the Puerto Rican workforce. The net migrant share gives the difference between the decadal change in the inmigrant and out-migrant shares. The " $\Delta$ " operator for the regressors indicates that these variables are defined as decadal changes. 


\section{Table 6. Joint determination of out-migration and weekly wages in Puerto Rico (IV estimates)}

\begin{tabular}{|c|c|c|c|c|}
\hline \multirow{3}{*}{$\underline{\text { Regressor }}$} & \multicolumn{4}{|c|}{ Dependent variable / Specification } \\
\hline & \multicolumn{2}{|c|}{$\begin{array}{l}\text { Decadal change in out- } \\
\text { migrant share } \\
\text { of Puerto Ricans }\end{array}$} & \multicolumn{2}{|c|}{$\begin{array}{c}\text { Decadal change in log } \\
\text { weekly earnings } \\
\text { in Puerto Rico }\end{array}$} \\
\hline & (1a) & $(2 a)$ & $(1 \mathrm{~b})$ & $(2 b)$ \\
\hline$\Delta$ (Mean log wage in U.S.) & $\begin{array}{c}0.673 \\
(0.203)\end{array}$ & --- & --- & --- \\
\hline$\Delta($ Mean log wage in Puerto Rico) & $\begin{array}{l}-0.183 \\
(0.068)\end{array}$ & --- & --- & --- \\
\hline$\Delta$ (Net log wage gain: U.S. - P.R.) & --- & $\begin{array}{c}0.129 \\
(0.040)\end{array}$ & --- & --- \\
\hline$\Delta($ In-migrant share $)$ & --- & --- & $\begin{array}{l}-0.523 \\
(0.263)\end{array}$ & --- \\
\hline$\Delta$ (Out-migrant share) & --- & --- & $\begin{array}{c}0.687 \\
(0.362)\end{array}$ & --- \\
\hline$\Delta$ (Net migrant share: In - Out) & --- & --- & --- & $\begin{array}{l}-0.769 \\
(0.577)\end{array}$ \\
\hline
\end{tabular}

Notes: Standard errors are reported in parentheses and are adjusted for clustering within education-experience cells. All regressions are weighted by the sum of sampling weights in the skill cell and have 60 education-experience-year cells. The out-migrant share gives the ratio of the number of out-migrants to the potential number of Puerto Ricanborn working men, and the in-migrant share gives the ratio of the number of in-migrants to the number of working men in Puerto Rico. The out-migrant share model uses the wage of native workers in the United States as the alternative wage. The " $\Delta$ " operator for the regressors indicates that these variables are defined as decadal changes. See the text for a detailed description of the instruments. 


\section{Table 7. Predicted wage impact of in-migration and out-migration in 1980-2000}

\begin{tabular}{|c|c|c|c|c|c|c|}
\hline \multirow[b]{3}{*}{$\begin{array}{l}\text { Wage elasticity: }-0.4 \text { for } \\
\text { in-migration and }-0.2 \text { for } \\
\text { out-migration }\end{array}$} & \multicolumn{2}{|c|}{$\% \Delta$ in supply due to: } & \multicolumn{3}{|c|}{$\Delta \log w$ due to: } & \multirow[b]{2}{*}{$\begin{array}{l}\text { 6. Actual } \\
\Delta \log w\end{array}$} \\
\hline & $\begin{array}{l}\text { 1. In- } \\
\text { migration }\end{array}$ & $\begin{array}{l}\text { 2. Out- } \\
\text { migration }\end{array}$ & $\begin{array}{l}\text { 3. In- } \\
\text { migration }\end{array}$ & $\begin{array}{l}\text { 4. Out- } \\
\text { migration }\end{array}$ & $\begin{array}{l}\text { 5. All } \\
\text { migration }\end{array}$ & \\
\hline & & & & & & \\
\hline All workers & 10.6 & -19.2 & -0.042 & 0.038 & -0.004 & 0.283 \\
\hline $\begin{array}{l}\text { High school dropouts, } \\
0-8\end{array}$ & 2.4 & +51.7 & -0.010 & -0.102 & -0.112 & 0.351 \\
\hline $\begin{array}{l}\text { High school dropouts, } \\
9-11\end{array}$ & 15.1 & +25.0 & -0.061 & -0.050 & -0.111 & 0.308 \\
\hline High school graduates & 7.5 & -34.9 & -0.030 & 0.070 & 0.040 & 0.243 \\
\hline Some college & 17.4 & -55.0 & -0.070 & 0.110 & 0.040 & 0.237 \\
\hline College graduates & 13.9 & -38.7 & -0.056 & 0.077 & 0.021 & 0.330 \\
\hline \multicolumn{7}{|l|}{$\begin{array}{l}\text { Wage elasticity: }-0.3 \text { for } \\
\text { in- and out-migration }\end{array}$} \\
\hline All workers & 10.6 & -19.2 & -0.032 & 0.058 & 0.026 & 0.283 \\
\hline $\begin{array}{l}\text { High school dropouts, } \\
0-8\end{array}$ & 2.4 & +51.2 & -0.007 & -0.154 & -0.161 & 0.351 \\
\hline $\begin{array}{l}\text { High school dropouts, } \\
9-11\end{array}$ & 15.1 & +25.0 & -0.045 & -0.075 & -0.120 & 0.308 \\
\hline High school graduates & 7.5 & -34.9 & -0.023 & 0.105 & 0.082 & 0.243 \\
\hline Some college & 17.4 & -55.0 & -0.052 & 0.165 & 0.113 & 0.237 \\
\hline College graduates & 13.9 & -38.7 & -0.042 & 0.116 & 0.074 & 0.330 \\
\hline
\end{tabular}

Notes: The variable measuring the group-specific in-migrant supply shock is defined as the number of in-migrants arriving between 1980 and 2000 divided by a baseline population equal to the average size of the Puerto Rican stayer workforce (over 1980-2000) plus the number of in-migrants in 1980. The variable measuring the out-migrant supply shock is defined as the number of persons who out-migrated between 1980 and 2000 divided by a baseline native population equal to the average size of the Puerto Rican stayer workforce (over 1980-2000) plus the number of in-migrants in 1980. The weighted averages reported for "all workers" use the number of workers in each education group as weights. 